University of Nebraska - Lincoln

DigitalCommons@University of Nebraska - Lincoln

Publications from USDA-ARS / UNL Faculty

U.S. Department of Agriculture: Agricultural

Research Service, Lincoln, Nebraska

1970

\title{
MITE TRANSMISSION OF PLANT VIRUSES
}

G.N. Oldfield

Follow this and additional works at: https://digitalcommons.unl.edu/usdaarsfacpub

This Article is brought to you for free and open access by the U.S. Department of Agriculture: Agricultural Research Service, Lincoln, Nebraska at DigitalCommons@University of Nebraska - Lincoln. It has been accepted for inclusion in Publications from USDA-ARS / UNL Faculty by an authorized administrator of DigitalCommons@University of Nebraska - Lincoln. 
U.S. government works are not subject to copyright.

Copyright 1970. All rights reserved.

\title{
MITE TRANSMISSION OF PIAANT VIRUSES
}

\author{
By G. N. OldFrecd \\ Entomology Research Division, Agricultural Research Service. \\ United States Department of Agriculture \\ Riverside, California
}

The subject of mite transmission of plant viruses has been reviewed several times by Slykhuis $(122,124,126,128)$. A considerable number of papers on this subject have been published since Slykhuis's last review; several constitute significant additions to the knowledge of the relationships between mites and the plant viruses they transmit.

Except, perhaps, for the apparent case of transmission of potato virus $Y$ by Tetranychus telarius (107), the only proven mite vectors of plant viruses are certain members of the family Eriophyidae. In 1927, Amos et al. (2) reported a positive correlation between the infestation of black currants with the black currant gall mite (Cecidophyopsis ribis) and the development of reversion disease. Each of the reports by Massee (69), Smith (135), and Thresh (145), which appeared much later, contributed to the incrimination of $C$. ribis as the vector of currant reversion virus. Shortly after Massee's report appeared in 1952 several other eriophyid mites were incriminated as vectors of plant viruses. Slykhuis $(118-120)$ reported that Aceria tulipae transmitted both wheat streak mosaic virus and wheat spot mosaic virus. Flock \& Wallace (34) reported that Aceria ficus transmitted fig mosaic virus. Wilson et al. (166) reported an undescribed species of Eriophyes [later described by Keifer \& Wilson and named E. insidiosus (60)] as a vector of the peach mosaic virus. Then Mulligan $(79,80)$ showed that $A b a-$ carus hystrix transmitted ryegrass mosaic virus.

Since Mulligan's report in 1958, a few additional cases of apparent eriophyid transmission of plant viruses have been reported; however, several of these need confirmation.

\section{CHARACTERISTICS OF ERIOPHYID MITES OF SIGNIFICANCE TO THEIR ROLE AS VECTORS OF PLANT VIRUSES}

Obviously, eriophyids are extremely small arthropods. They range from about $90 \mu$ long in the case of Heterotergum wilsoni to well over $300 \mu$ long in the case of Novophytoptus stipae. Most species range between 150 and $225 \mu$ long. Because of their diminutive size, they have often been overlooked as vector candidates. The small size allows them to occupy areas on

${ }^{2}$ The author wishes to acknowletge the help extended by Prof. I. M. Newell and $\mathrm{Mr}$. N. S. Wilson during the course of this study. 
the plant that are inaccessible to larger organisms and allows the production of huge populations in comparatively small areas.

Eriophyids are well known for their ability to cause a wide array of galls, each type of which is usually characteristic of a certain mite species. However, many species do not cause galls and are often considered as causing no damage to their hosts. Many species cause rather subtle changes in their hosts such as the slight curling or twisting of leaves. Certain of these changes are often overlooked. Under certain circumstances, as in the case of Aculus mites on Prumus spp. (40,158, 164), symptoms of feeding injury on leaves may closely resemble symptoms of virus infection. In cases such as these, precautions must be taken to distinguish between feeding injury and symptoms of virus infection.

Eriophyids exhibit several types of life cycles $(44,53,89)$; however, all of the types of life cycles are completed on a single host. While in certain cases (deutogynes) eriophyids do not feed for several months, they nevertheless do not leave the host plant except to establish themselves on another plant.

Eriophyids may be disseminated by wind $(119,132)$ or may be transported by other insects $(39,67,132,162)$. They often are observed in an upright position resting on the caudum and apparently become airborne from this position. Eriophyids exhibit varying degrees of host specificity. There appears to be some basis for generalizing that species that have a more intimate relationship with their hosts (i.e., gall formers and bud inhabitants) are usually more host-specific than species that function as leaf vagrants. Often, gall-forming species are limited to a single species or group of species within a genus of plants. Leaf-vagrant species may be equally host-specific or, as in the case of Calacarus citrifolii in South Africa (155), they may have a host range including plants in several families. As will be discussed in this paper, Aceria tulipae also has a wide host range, but all of its hosts are monocots.

All eriophyids are essentially parasites of perennial plants. However, some annuals may become infested from closely related perennials. In the case of $A$. tulipae, wheat, an annual, may become infested by mites from perennial plants or, in areas where wheat grows in overlapping sequence, $A$. tulipae may be perpetuated on this annual.

The mouthparts of eriophyids are specifically adapted for picrcing plant cells. The length of the chelicerae suggests that they are able to penetrate only a very few cell layers of plant tissue. Phyllocoptruta oleivora, the citrus rust mite (100), usually penetrates only the epidermal cell layer of orange rinds. Orlob (92) suggested that because of the structure and attachment of the stylets and rostrum, $A$. tulipae probably only penetrates five $\mu$ into plant tissue; i.e., only into the epidermal cells.

Because of their diminutive size, eriophyids pose problems not often encountered in working with other arthropod taxa that transmit plant viruses. In most other taxa, individuals are large enough to be transferred and sub- 
sequently recovered from test plants after a prescribed transmission period. In this case, the appearance-and more importantly, the persistence and development of disease symptoms-is usually considered evidence of transmission of an etiological agent by the arthropod. On the other hand, the failure of symptoms to persist and spread would suggest that they were caused by a phytotoxic substance injected by and inherent to the arthropod.

Because of their propensity for finding their way into buds and other protected places on their hosts (and their small size), it is extremely diffcult to recover even the majority of individual eriophyids after transferring them from one plant to another. For this reason, special techniques must be used to show that abnormalities which may subsequently appear in a test plant after introducing eriophyids are due to transmission of a virus by the mites and not due to injection of a phytotoxic substance.

Slykhuis (126) suggested the following three conditions that must be met to prove that an eriophyid is a vector of a plant virus: $(a)$. The presence of mites must be correlated with the appearance of the disease in nature. (b). The development of disease symptoms must not depend on the continued presence of the mites. It is preferable if the causal virus can also be transmitted by artificial means without mites. $(c)$. The mites must not be able to induce the disease symptoms on healthy plants until after they have fed on diseased plants or have acquired virus in some other way.

In regard to the second condition, certain mite-transmitted viruses are sap-transmissible. In this case, the test plant can be tested for the presence of virus with minimum precautions against transfer of mites in the sap to another plant. Other mite-transmitted viruses are not sap-transmissible but can be mechanically transmitted only by grafting. In this case, far greater measures must be taken to insurc that eriophyids are not transferred on the grafted tissue since what may in reality be continued transfer of a toxocogenic eriophyid from plant to plant, may appear to be evidence of virus transmission if all eriophyids are not destroyed. Flock \& Wallace (34) used sulfur dust to kill Aceria ficus after allowing them to feed on test plants for a prescribed time. There are arguments against complete reliance on this technique to prove virus transmission since it is almost impossible to certify that the population of mites is completely destroyed. Nevertheless, the extension of this technique or other similar techniques is useful to preclude the transfer of live mites from a test plant with disease symptoms to a healthy mite-free plant during grafting.

\section{WHEAT STREAK MOSAIC}

The Vector

Geographical distribution.-Aceria tulipae was originally described from tulips in California by Keifer (52). The tulips were said to have originated in Holland. Reports from several areas in the United States $(4,24,27,92$, $140)$ and from Canada $(95,123)$ of transmission of wheat streak mosaic 
virus (WSMV) by $A$. tulipae indicate that this species is widespread in North America. In South America, it has been reported from Venezuela (29) and Argentina (105). Puttarudriah \& Channabasavanna (102) reported an eriophyid mite as a pest of garlic in Mysore, India. The general description of damage, mite anatomy, and distribution of mites on the plant suggested that it may be $A$. tulipme. Shtein-Margolina et al. (111) and Oliinyk (91) reported studies using $A$. tulipae from Russia. It is probably widespread throughout the Holarctic Region.

Feeding injury.-In 1961, A. tulipae was implicated as the cause of "silver top" disease of grasses in southern Alberta, Canada (45); however, a later report (3) indicated that silver top is caused by certain insects and not by $A$.tulipae. Recently, Nault et al. (84) reported that a salivary phytotoxin injected by $A$. tulipae caused red streak of corn. It also damages garlic in California (62) and Venezuela (29). According to Smalley (131), it can cause virus-like symptoms on garlic.

Host range.-A. tulipae has a wide range of hosts in the Gramineae. Slykhuis (119) reared it on Poa compressa and Oryzopsis hymenoides as well as on wheat. Connin (23) found $A$. tulipae naturally infesting western wheat grass (Agropyron smithii), Canada wild rye (Elymus canadensis), green foxtail (Setaria viridis), smooth crabgrass (Digitaria ischaemum), and oversummering volunteer wheat (Triticum aestivum). In greenhouse studies (24), A. tulipae reproduced on all 27 varieties of wheat tested, all 6 barley varieties tested, all 10 corn varieties tested, all 5 sudan grass varieties tested, and 12 of 24 wild grass species tested.

According to Slykhuis (128), as yet no perennial has been shown to function as an important source of spread of the virus because apparently none are good hosts of both $A$. tulipae and wheat streak mosaic virus. Gibson (37) observed that sorghum, sprouted under wheat that was infested with $A$. tulipae, was apparently not a good host. Slykhuis (119) collected $A$. tulipae from the field on foxtail barley (Hordeum jubatum), Canada wild rye, and western wheat grass and found that they did not survive when placed on wheat, and $A$. tulipae from wheat did not survive when placed on any of the other three grasses. According to Del Rosario \& Sill (27), physiological strains of $A$. tulipae that are adapted to wheat, western wheat grass, and onion do not readily colonize the other two hosts in each case. Such a phenomenon might account for the apparent unimportance of wild grasses as sources of spread of the virus.

Biology.-According to Staples \& Allington (140), the life cycle of $A$. tulipae includes the egg, two nymphal stages and the adult. The nymphs are incapable of gross movements for several hours before molting. On wheat, reproduction is apparently entirely parthenogenetic. The life cycle described by Staples \& Allington is typical of many eriophyid species. According to Gibson [cited by Somsen (139)], no specialized overwintering female (deutogyne) is produced, but Somsen (139) reported the existence of a "migratory form" which was larger and less prone to injury during transfer. Som- 
sen stated that differences between the so-called "migratory form" and the usual adult were difficult to quantify, but he suggested that the "migratory form" might account for the appearance of sudden epiphytotics of wheat streak mosaic. Somsen's report is indeed interesting; inasmuch as it is, as far as I know, the first report of such a form in the Eriophyidae. I have observed extremely large adults in certain Eriophyes species, but I have not attempted to show that they represent a significantly different morphological type or relate their appearance to any annual event or change in the host plant.

Slykhuis (119) showed that eggs of $A$. tulipae from southern Alberta, Canada, could survive when exposed to $-30.7^{\circ} \mathrm{C}$ for 2.5 minutes. In general, $A$. tulipae survived lower temperatures than host wheat plants. Slykhuis also showed that hatchability of $A$. tulipae eggs was highest at 100 per cent relative humidity. Del Rosario \& Sill (25) found that successful rearing required rather high humidity. They were able to herd the negatively phototactic mites with a beam of light. Del Rosario \& Sill (26) studied reproductive potential and other aspects of the biology of $A$. tulipae. They were able to keep adult mites alive on a wheat-decoction-dextrose agar culture media for periods up to 80 days but none reproduced.

\section{The Virus}

Geographical distribution,-The disease now known as wheat streak mosaic was first reported in 1929 (70) from Kansas. It caused heavy losses of wheat yield in western Kansas during 1949 and 1954 (31, 216). Also, it has caused serious losses to wheat in other great plains areas including $\mathrm{Ne}-$ braska (140), South Dakota (117); Wyoming (161), Colorado (5), Montana (77), and southern Alberta, Canada (118). In 1965, Slykhuis (128) reported finding it in southwestern Saskatchewan, Canada. It has also been reported from wheat in North Dakota (153), Iowa $(35,160)$, California (46), Oklahoma (159), Ohio (72), Washington (78), and Texas (4). In Europe, wheat streak mosaic has been reported from Yugoslavia (142), U.S.S.R. (104), and Rumania (98). Slykhuis (125) found wheat streak mosaic virus in Jordan but not in Australia, New Zealand, West Pakistan, India, Iran, or Egypt. In 1957, Finley (33) found corn infected with wheat streak mosaic in Idaho. More recently, wheat streak mosaic virus was found naturally infecting corn in Nebraska (47), Iowa $(35)$, and Ohio $(72,163)$.

Host range.--Several workers have studied the host range of wheat streak mosaic virus. McKinney (71) found that all 39 varieties of wheat tested were susceptible as were certain varieties of barley, oats, and corn. McKinney \& Sando (74) found each of 18 varieties of wheat to be very susceptible but found none of 16 species of Agropyron grasses to be systemically infected (only six showed local lesions). Hybrids of Agropyron and wheat were generally less susceptible than wheat. McKinney \& Fellows (73) found certain annual and perennial representatives of 13 additional genera of grasses to be susceptible. Later, Fellows \& Schmidt (32) reported a wide 
diversity of reactions among several Agropyron-wheat hybrids, but even the symptomless hybrids carried the virus.

Apparently, while wheat streak mosaic virus has a wide host range in the Graminac, it docs not infect species in other families. Sill \& Connin (113) listed 41 species in 20 dicot families that were shown to be immune. Sill \& Agusiobo (112) reported certain varieties of oats, barley, rye, and corn as susceptible, but none of 27 species in other 13 monocot families were susceptible. Notably, these included onion and tulip-two species long recognized as hosts of $A$. tulipae. These investigators also tested several dicot species; all were immune.

Morphology and other characteristics.-Much more is known about wheat streak mosaic virus than any other eriophyid mite-borne virus. Gold et al. (42) observed elongated particles about $15 \mathrm{~m} \mu \times 670 \mathrm{~m} \mu$ in electron micrographs of juice extracts from WSMV-infected wheat leaves but none in juice extracts of healthy wheat leaves. Brakke (11) succeeded in purifying the virus from infected wheat. Brakke \& Staples (12) showed that particles shorter than $650 \mathrm{~m} \mu$ were not infective and Brandes \& Wetter (13) found that WSMV particles were consistently much longer than those of barley stripe mosaic virus and soil-borne wheat mosaic virus. Shepard \& Carroll (110) recently observed typical rod-shaped particles of WSMV in transverse and tangential section in the cytoplasm but not in the nucleus, chloroplasts, or mitochondria of infected cells of wheat and barley. No such particles were found in cells of healthy plants. Particle morphology agreed with that reported earlier by Brakke \& Staples (12).

Recently, Paliwal \& Slykhuis (95) found particles corresponding in size to WSMV particles in infected wheat plants and infective $A$. tulipae but not in healthy wheat plants or noninfective $A$. tulipae. Also, Oliinyk (91) found similar particles in macerates of infective $A$. tulipae.

\section{Mite-Virus RELATIONSHips}

Several characteristics of the vector, host plant, and virus have enabled workers to learn much about the transmission of WSMV that remains unanswered for other mite-transmitted viruses. The vector, A. tulipae, is relatively easy to colonize on wheat plants. The relatively small size and the fact that it is an annual enables easy manipulation, culturing, and isolation of the test plant.

Recently, Slykhuis (129) reviewed methods and apparatus for experimenting with eriophyid mite-transmitted viruses. Many of these are applicable to studies of eriophyid mite transmission of grass viruses but are of little value for studying those eriophyid mite-transmitted viruses of woody perennials. Transmission studies of WSMV are also facilitated by the fact that it is readily sap-transmissible, and the latent period in wheat is very short. Slykhuis (119) reported that symptoms appeared about a week after inoculation. Sill \& Fellows (115) reported that, following sap inoculation, the time required for sympton expression was five days at $82^{\circ} \mathrm{F}$ and nine days 
at $68^{\circ} \mathrm{F}$. Del Rosario \& Sill (27) indicated that symptoms appeared about a week after inoculation, but they were able to reisolate the virus both by sap inoculation and using $A$. tulipae after two full days following inoculation.

Wheat streak mosaic virus is the only eriophyid mite-transmitted virus in which several investigators have effected transmission using the vector. After Slykhuis's (118) original report, several others in North America (4, $24,27,92,95,140)$ and U.S.S.R. $(91,111)$ successfully transmitted this virus using $A$. tulipae.

Connin (24) showed that A. tulipae was able to transmit WSMV to all 27 wheat varieties tcsted plus several varieties of oats, barley, and several spccies of wild grass. Sill \& Del Rosario (114) showed that $A$. tulipae could transmit WSMV from wheat to corn and back to wheat. These authors (27) found wide differences in vector efficiency among populations of $A$. $t u$ lipae collected in the field from various host species. A. tulipae from $A$. smithii was an extremely inefficient vector to wheat (1 per cent) but improved after the mites "adapted" to wheat ( 32 per cent); however, this strain was still a far less efficient vector from wheat to wheat than a strain that occurred naturally on wheat. The latter strain showed an 84 to 92 per cent vector efficiency from wheat to wheat. A. tulipae that occurred naturally on wheat was an efficient vector to virus-susceptible corn varieties and the mites from wheat adapted to corn easily.

In Slykhuis's (119) report of transmission of WSMV using A. tulipae, he transferred eggs to separate groups of healthy wheat seedlings and manually inoculated one group with WSMV. Then he demonstrated that $A$. tulipae from the infected plants transmitted the virus, but those from healthy plants did not. Slykhuis (119), Del Rosario \& Sill (27), and Orlob (92) all showed that WSMV was not transmitted transovarially but by the adult and both nymphal stages. They agreed that both nymphal stages acquired the virus. Also, by successfully inoculating wheat plants with WSMV using macerates of nymphs, Orlob (92) demonstrated that they acquired the virus. Slykhuis (119), Del Rosario \& Sill (27), and Orlob (92) found that the adult was unable to transmit WSMV unless it had access to the virus before reaching the adult stage. Slykhuis and Del Rosario \& Sill considered this evidence that the adult could not acquire the virus. Yet, Orlob succeeded in inoculating plants manually with WSMV using macerated adults that had access to the virus only after becoming adults and thus showed that they do acquire the virus.

Orlob showed that young adults are efficient vectors but soon become poor vectors. Young adults and second-stage nymphs were quite efficient. In transfers of one individual per plant, efficiencies ranged from about 40 per cent to 67 per cent. First-stage nymphs were less efficient, but this was probably partly due to an observed higher mortality among first instars than among older stages following transfer.

Orlob also studied acquisition of the virus by $A$. tulipae. When mites were given a 10-minute virus-acquisition feeding period and then trans- 
ferred one per plant to 116 susceptible plants, none of the plants became infected. With a 15-minute virus-acquisition period, two of 173 plants became infected. There was a linear relationship between length of acquisition-feeding period and percentage of plants that became infected. With a 16-hour acquisition-feeding period (the longest period tested), about half of the plants to which mites were transferred became infected.

Orlob obtained very similar results in studies of the inoculation-feeding period. When mites were given a 10 -minute inoculation-feeding period, no infection of the plants resulted. A very low percentage of plants became infected when mites were given a 15 -minute inoculation feeding period. The percentage of infections increased linearly as the inoculation feeding period was increased until at 16 hours almost half of the plants became infected. Orlob suggested that the increased transmission with an increase in time was due to an increased probability that the virus was deposited in the proper site.

It is generally agreed that WSMV persists in A. tulipae for at least a few days. By transferring infective mites to immune hosts and then transferring groups of mites from the immune host to susceptible wheat plants at daily intervals, Slykhuis (119) showed that WSMV was retained in A.tulipae for at least six days. Del Rosario \& Sill (27) used a similar technique and found that there was no loss in infectivity of A. tulipae for at least four days after being transferred to immune hosts. Also, they transferred $A$. tulipae to a wheat-dextrose decoction agar that was found to sustain adults (but upon which no reproduction occurred) and, upon removing mites to susceptible wheat plants at various intervals, they found that the virus had persisted for 18 days. Infectivity of the mites remained quite high through the 11th day on agar, then it rapidly decreased through the next week. Using Slykhuis's technique, Orlob (92) demonstrated transmission by $A$. tulipae seven days after transfer to immune hosts when held at $23^{\circ}$ to $28^{\circ} \mathrm{C}$ and 61 days after transfer to immune hosts when held at $3^{\circ} \mathrm{C}$.

Orlob offered additional evidence of the persistence of WSMV. He demonstrated persistence through the molt by transferring immobile, molting nymphs from infected plants to healthy plants and effecting transmission. Also, he immersed infective $A$. tulipae in a 1 per cent formaldehyde bath for 2 minutes (a treatment that inactivates WSMV in leaf extracts) and found that no loss in ability to transmit the virus had occurred. Orlob considered these results as evidence of "the persistent or circulatory type of virus-vector relationship."

Orlob successfully inoculated plants with WSMV using macerates of $A$. tulipae nymphs and adults that were reared on infected wheat plants, but he was unable to inoculate plants using macerates of Aculus mckenziei or $A b a-$ carus hystrix treated similarly. (These two eriophyid species occur on wheat in nature but do not transmit WSMV.) Orlob found particles analogous to WSMV particles in homogenates of both A. tulipae and the other two species when they fed on infected wheat. (Oliinyk (91) reported find- 
ing similar particles in macerates of infective $A$. tulipae and infected wheat.) Orlob failed to find virus-like particles in the two nonvectors after they had fed on healthy wheat. He suggested that perhaps the virus was inactivated by the nonvectors. Paliwal \& Slykhuis (95) reported a positive reaction between antiserum for WSMV and extracts of $A$. tulipae from infected plants but reported that WSMV antiserum did not react serologically with extracts of $A$. tulipae from healthy plants or extracts of the same two nonvector species used by Orlob that had been reared on infected plants. Paliwal \& Slykhuis corroborated Orlob's results in which he successfully inoculated wheat plants with macerates of infective $A$. tulipae but not with noninfective $A$. tulipae or the two nonvector species that were reared on infected wheat. As Orlob had, they observed particles analogous to WSMV particles in $A$. tulipae from infected plants but failed to find them in $A$. tulipae from healthy plants. Unfortunately, they did not study homogenates of the two nonvector species; consequently, that part of Orlob's work has not yet been duplicated.

Paliwal \& Slykhuis also observed WSMV-like particles in ultrathin sections of infective $A$. tulipae. They observed large numbers of WSMV-like particles in 7 of 13 individuals from infected wheat but failed to find similar particles in 10 individuals from healthy wheat. The greatest concentration of particles was found in the lumens of the hindgut and posterior part of the midgut. They did not find similar particles within any of the mite tissues. They also prepared whole mounts of $A$. tulipae and examined the internal organs with the light microscope. They found that the alimentary canal is essentially a simple tube in which the midgut and hindgut are connected by a narrow tube that becomes indistinct, perhaps because of degeneration, in older adults. In the adults, the anterior part of the midgut almost closes due to the pressure caused by the maturation of eggs and the development of nutritive tissue. They suggested that the inability of the adult to become infective may be related to these differences between nymphs and mature adults. These investigators pointed out that the concentration of the virus in the lumen of the gut and the absence of virus in any tissue of the vector indicated that while the virus is persistent, it is not circulative in the vector. They suggested that backflow to the mouthparts or elimination of infective virus from the anus or both, might be involved in its transmission. In the case of defecation, they suggested that feeding punctures or the action of the anal setae or anal sucker could cause abrasion adequate to introduce freshly eliminated virus into epidermal cells.

Shtein-Margolina et al. (111) found polygonal particles in ultrathin sections of infected plant tissue and tissues of infective $A$. tulipae. They found rods analogous to WSMV in suspensions of infected wheat tissue but failed to explain the relationship between the polygonal particles and the rods. The diameter of the polygonal particles and the electron transparency of the central area suggested that these were transverse sections of WSMV rods; however, the authors did not discuss this possibility. They considered 
their findings evidence that WSMV reproduces in tissues of $A$. tulipae. This, of course, is contrary to Paliwal \& Slykhuis's report.

The investigation of latency in the vector (as well as additional electron micrographic studies) might help to elucidate the relationship between $A$. tulipae and WSMV. Orlob (92) showed that $A$. tulipae can acquire enough virus within 10 minutes to cause infection of a healthy plant; however, we do not know if there is a period after acquisition in which the mite is unable to transmit the virus. The demonstration of a considerably long latent period after acquisition would suggest that the virus passes through tissues of the mite-and perhaps multiplies-before being transmitted. No latent period or a short latent period would appear to favor Paliwal \& Slykhuis's hypothesis. It is well to keep in mind that these relationships are unknown for other eriophyid mite-transmitted viruses. Perhaps the case of WSMV and its vector will prove to be uniquely different than any of the relationships reported for insects and the viruses they transmit.

\section{EpIDEMIOLOGX}

Although both WSMV and $A$. tulipae have many hosts among the grasses, and $A$. tulipae has other monocot hosts, none of the other monocot hosts of $A$. tulipae are hosts of WSMV; consequently, their role in its spread is, at most, only one of sustaining populations of the vector. Furthermore, Del Rosario \& Sill (27) showed that $A$. tulipae from onion did not readily colonize wheat, but it finally became "adapted" to wheat. They showed that even after adaptation it was not an efficient vector of WSMV compared to $A$. tulipae which occurred naturally on wheat. As mentioned earlier, Slykhuis (119) was unable to rear $A$. tulipae from wheat on several grass species upon which $A$. tulipae had been found reproducing. Likewise, A. tulipae occurring naturally on several wild grass species would not colonize wheat. Also, Orlob (93) reported that $A$. tulipae from several grasses did not really adapt to wheat.

The identity of the various populations that are considered to be $A$.tulipae should be investigated in greater detail inasmuch as the reports cited above suggest that some of the taxa which, by present criteria, are considered to be $A$. tulipae may be closely related but distinct from it. A further elucidation of the relationships among the various populations currently referred to as $A$. tulipae might contribute considerably to an understanding of the epidemiology of WSMV.

Several investigators have sought to explain the factors that accounted for epiphytotics in certain areas. According to Slykhuis (119), the important phases in the annual cycle of wheat streak mosaic appeared to be associated with living wheat plants. Since both the vector and the virus overwinter in winter wheat and move to spring wheat or volunteer wheat the following spring, summer fallow must be kept free of volunteer wheat for a sufficient period to prevent a subsequent serious outbreak of WSMV. Also, Connin (23) recognized the epidemiological importance of oversummering 
volunteer wheat. King \& Sill (61) stressed the importance of the unusually long warm period during fall that allowed the development of huge populations of A. tulipae and resulted in an epiphytotic in Kansas during 1959. Slykhuis et al. (130) emphasized the importance of diseased immature wheat as foci from which infective $A$. tulipae spread to newly planted winter wheat. In southern Alberta, Canada, losses due to wheat streak mosaic were greatest in winter wheat seeded before nearby winter or spring wheat had matured.

In Washington (15), the lack of summer rain and the resulting small reservoir of oversummering host plants apparently precludes appreciable spread of $A$. tulipae and serious losses from wheat streak mosaic. Atkinson \& Slykhuis (6) related a severe outbreak of wheat streak mosaic in southern Alberta to a spring drought which delayed development of spring grains to the extent that $A$. tulipae and WSMV spread from the immature wheat to the newly planted winter wheat crop.

According to Gibson \& Painter (38), Kantack and Knutson found large numbers of $A$. tulipae on ripening kernels of winter wheat and observed that volunteer wheat resulting from hail immediately became infested with A. tulipae. Gibson \& Painter (38) showed that A. tulipae infesting wheat kernels could move directly from the kernels to the resulting wheat seedlings. Perhaps this phenomenon and the demonstrated persistence of WSMV in A. tulipae might result in immediate infection of new wheat seed lings with the virus.

Most of the evidence suggests a minor epidemiological role for wild perennial and annual grasses $(93,119)$, but corn may be epidemiologically important where both corn and wheat are grown, inasmuch as many varieties are hosts of WSMV (47). On the other hand, Sill \& Del Rosario.(114) found that all field corn varieties that they tested were resistant to WSMV and only a few sweet corn varieties were damaged, yet they found that $A$. tulipae could transmit WSMV from wheat to corn and from corn to wheat. They suggested that corn might be a possible oversummering reservoir for A. tulipae and WSMV. Other investigators $(72,163)$ recently reported the isolation of WSMV from diseased corn and wheat in Ohio.

\section{WHEAT SPOT MOSAIC}

This virus disease was discovered by Slykhuis $(118,119)$ in the course of studies that proved that $A$. tulipae transmitted WSMV. Unlike wheat streak mosaic, wheat spot mosaic has not been found outside southern Alberta, Canada. Slykhuis (127) reported that he reisolated it in 1958, but its severe pathogenicity complicated lengthy culturing in wheat.

While studying WSMV transmission, Slykhuis (119) transferred $A$. $t u$ lipae from certain wheat plants that showed severe chlorotic mottling in the field to healthy wheat plants in the greenhouse. Over half of the greenhouse plants developed symptoms similar to the field plants from which $A$. tulipae had been collected; however, WSMV could be sap-transmitted to healthy 
wheat plants from only about half of the plants that showed symptoms after transferring $A$. tulipae to them. In another experiment, he transmitted WSMV both manually and with $A$. tulipae from five of ten severely chlorotic, stunted wheat plants in the field. A. tulipae from the five other plants induced severe chlorotic symptoms, but the presence of WSMV could not be demonstrated by manual inoculation of healthy plants. Slykhuis suggested that a nonsap-transmissible virus was probably involved.

The inability to sap-inoculate this entity necessitated that other measures be taken to show conclusively that symptoms were due to a virus transmitted by $A$. tulipae and not to feeding injury by the mite. Slykhuis (120) accomplished this by destroying the populations of $A$. tulipae on the plants that showed wheat spot mosaic symptoms and observing a subsequent reappearance of symptoms in the absence of mites.

Also, he established colonies of $A$. tulipae by transferring eggs from plants showing wheat spot mosaic symptoms to healthy plants. The absence of symptoms indicated that the virus was not transovarially transmitted. Then, he transferred mites from the healthy plants and mites from plants showing wheat spot mosaic symptoms to separate groups of healthy plants and found that symptoms of wheat spot mosaic appeared only on plants receiving $A$. tulipae from diseased plants. He further showed that $A$. tulipae from healthy plants could transmit wheat spot mosaic virus when given a seven-day acquisition-feeding period on infected wheat. Also, he found that the adult and both nymphal stages were able to transmit this virus and it was retained through the molts.

In one series of comparative tests with individual mites, 65 per cent transmitted wheat spot mosaic virus and 34 per cent transmitted wheat streak mosaic virus (128). Mites remained infective for 13 days on Lolium perenne, a species that is immune to the virus. Single $A$. tulipae could simultaneously carry both WSMV and wheat spot mosaic virus.

In greenhouse tests, Slykhuis (120) showed that wheat spot mosaic virus infected several graminaceous hosts including cultivated varieties of wheat, corn, barley, and Hungarian millet as well as the wild grass species, Setaria verticillata, S. viridis, and Eragrostis cilianensis. Oats and several species of wild grasses showed no symptoms of wheat spot mosaic.

While its severe pathogenicity and the inability to sap-transmit it are complicating factors in studying wheat spot mosaic virus, the ease with which both the host plant and vector can be reared and the basic attractiveness of studying the interrelationships between a mite vector and two plant viruses that can be carried simultaneously, would appear to be ample reason to conduct further studies of this virus.

\section{RYEGRASS MOSAIC}

Ryegrass mosaic virus (RMV) causes pale-green streaks on ryegrass leaves in England, Wales, Scotland, and several countries of northern Europe (121). Slykhuis (121) and Mulligan (80) credited each other with 
transmitting ryegrass mosaic virus with a mixed colony of eriophyid mites. After obtaining identifications of the various species in the mixed colony, Mulligan $(79,80)$ obtained pure colonies of Abacarus hystrix by single transfers from infected plants and succeeded in demonstrating its ability to transmit the virus. He showed that $A$. hystrix could transmit the virus after as little as a 2-hour acquisition-feeding period. He also stated that the various instars transmitted ryegrass mosaic virus equally often but showed no supporting data. Also, Mulligan studied persistence of the virus in A. hystrix by transferring infective mites to virus-immune wheat plants that supported $A$. hystrix. On three occasions the virus was transmitted after 6 hours, but not after 12 hours on the immune wheat.

Mulligan studied electron micrographs of clarified sap from healthy and infected plants and found that only the infected plants contained flexuous rods. He presumed these were ryegrass mosaic virus particles. $\mathrm{He}$ was able to sap-inoculate many British grasses with ryegrass mosaic virus. $A$. hystrix transmitted RMV to Blenda oats but not to Proctor barley or Capelle wheat, although both were suitable hosts for infective $A$. hystrix. Also, timothy was immune to the virus. Mulligan tested several dicotyledonous species; all were immune. He did not list the dicotyledons that he tested.

According to Keifer (54) A. hystrix lives on the upper surface furrows of the leaves and has a wide distribution on perennial grasses throughout the Northern Hemisphere. Keifer suggested the common name "cereal rust mite" for this species. According to Keifer (56), Abacarus oryzae, a species that infects rice plants in the Philippines, is very similar to $A$. hystrix. In the description of the closely related $A$. oryzae, Keifer stated "The mites ... are said to have come from plants (rice) affected with dwarf disease called 'tungro." "

Although there are no other reports of diseases of rye being transmitted by eriophyids, and no account of the role of $A$. hystrix as vector of ryegrass mosaic virus has appeared since Mulligan's paper, a mosaic disease of Italian ryegrass was reported from western Washington in 1957 (16). A year later, A. hystrix was found in Washington (15). The relationship of this disease to the eriophyid-borne mosaic of ryegrass apparently has not been investigated.

\section{CURRANT REVERSION}

Reversion of black currant is so named because plants with this disease resemble wild uncultivated Ribes nigrum; i.e., they revert to the wild type. Reversion has long been recognized as a serious disorder of black currants in the British Isles. According to Smith (138), it is widespread in the British Isles and probably occurs throughout northern Europe. Slykhuis (128) cited reports of currant reversion from several northern European countries. McLarty (75) reported "reversion" on currants in British Columbia, but his evidence was fragmentary at best.

The study of the epidemiology of reversion has been mainly a study of 
the relationship between reversion and the black currant gall mite (or big bud mite), Cecidophyopsis ribis, inasmuch as the relationship between the incidence of big buds caused by $C$. ribis and reversion of black currants was recognized quite early.

\section{The Vector}

Geographical distribution and host range.-This species apparently occurs in most areas where black currants are grown. According to Mumford (81), it occurs in the British Isles, Denmark, Germany, the Netherlands, Russia, Sweden, Norway, Finland, and British Columbia. Mumford listed the following Ribes spp. as the only known hosts of $C$. ribis: $R$. nigrum, $R$. rubrum, $R$. alpinum, $R$. grossularia, and $R$. sanguineum. Both Warburton \& Embleton (162) and Massee (67) reported finding $C$. ribis in buds of $R$. rubrum and $R$. nigrum, but they agreed that on $R$. rubrum the buds were not swollen as in $R$. nigrum.

Recently, van Eyndhoven (156) described Cecidophyopsis selachodon as a new species of gall mite from $R$. rubrum in the Netherlands. Later, Boczek (10) reported this species from Poland. Morphologically, C. selachodon and $C$. ribis are quite similar. These reports naturally raise the question of the identity of eriophyid mites reported earlier from other Ribes spp. and considered to be $C$. ribis.

Biology.-C. ribis spends most of the year in the buds, but during the spring it leaves the buds and subsequently enters new buds. There has been considerable disagreement regarding the activities of mites during emigration from old buds to new ones. Earlier, workers gave seemingly authoritative but often conflicting accounts of the behavior of $C$. ribis during this period. Warburton \& Embleton (162) found individuals in leaf axils during the migration period and noted that those that left the older buds were mostly adults. Massee (68) reviewed earlier accounts of the big bud mite's life history and reported his own observations. Taylor (cited by Massee) said that the mites distributed themselves on the outer surface of the big buds and dispersed by leaping. When one alighted on a leaf, it proceeded to the petiole and disappeared between the upper surface of the petiole and the twig where a new bud eventually emerged. Massee reported that during migration to new buds in the spring, eggs are laid on the young shoots and flowers. He also reported that eggs were laid on the leaves and shoots during summer and stated "It has been noted that the mites (C. ribis) copulate on the leaves prior to entering buds." He said that both immatures and adults migrated. Amos et al. (2) reported that the C. ribis adult population consisted of about 98 per cent females.

Recently, Collingwood \& Brock (21) and Smith $(132,134)$ studied various aspects of the biology of $C$. ribis. During December, no eggs were laid; egg production began in January and reached a peak in March (21). Mites were ready to leave the buds by mid-February but were unable to escape until the buds opened in March (132). At that time populations averaged 
about 30,000 per bud (21). Populations in the buds decreased rapidly once emergence began. Using a suction apparatus connected to a timer, Smith (132) found that at $80^{\circ} \mathrm{F}$, the rate of emergence from the buds was about 800 per hour.

Upon emerging from the buds, the mites often stood erect on their anal suckers and leaped from the bud by contracting the muscles on one side and springing. In still air, mites were capable of leaping about two inches. Under experimental conditions, mites left the bud in increasing numbers at wind velocities up to $24 \mathrm{mph}$; but as velocities increased above that air speed, the mites showed a decreasing tendency to become erect and fewer left the bud (132).

Warburton \& Embleton (162), Massee (68), and Smith (132) mentioned finding $C$. ribis attached to several arthropods during the period of migration. Smith (132) found that mites remained attached to a tethered aphid for 5 to 10 minutes at a wind velocity of $20 \mathrm{mph}$. At $3 \mathrm{mph}$, mites remained attached to the aphid for 6 hours. The mites immediately released themselves upon contacting an object.

Mites that did not leap from the buds or attach to animals crawled in all directions on the bud; but upon reaching the stem, they exhibited a directional response and moved upward (66). Smith (132) stated that the upward movement was a positive phototactic response and no geotaxis was involved.

Mites were detected moving along the new shoot growth for a threemonth period during the spring. The protracted migration period resulted from the gradual opening and drying of infested buds which exposed an increasing portion of the mite population. During this period the buds swelled, the blossoms appeared, and the fruit set and attained most of its size (21).

Individual mites were unable to exist outside the buds for long periods. Smith (132) removed buds during March and found that individuals that had reached the stem could survive for only a few days even under the shelter offered by normally developing leaf tissue. He found mites in appreciable numbers only on stems and leaf axils, i.e., the shortest routes between old infested buds and new axillary buds. Unlike Massee (68), he found mites on exposed leaves and blossoms only occasionally. Neither Collingwood \& Brock $(21)$ nor Smith $(132,134)$ mentioned finding $C$. ribis eggs outside bud galls. Thresh (151) never found eggs until the dispersal period was over and then he found them only on leaf primordia and meristems of new buds. Smith (132) stated that $C$. ribis moved toward higher humidity and suggested that was the reason they moved toward leaf axils. When mites arrived at the leaf axils, they proceeded to penetrate the new bud tissue by crawling inside the outer scale leaves and continuing in a circular direction until they reached the center of the bud. As a result they were usually concentrated near the apical meristem. Penetration took an average of 32 hours during postblossom time.

According to Smith (134), desiccation is probably the most important 
mortality factor during the migration period, but starvation is probably also important. Smith considered predation by polyphagous arthropods of little importance as a mortality factor during this period. Many mites perished during penetration of the buds.

Smith (132) found that mites which emerged from infested buds later in the spring were less likely to produce galls because they had to move farther up the shoot to reach suitable buds and were, therefore, more likely to fall victim to any of several mortality factors. Even so, when placed on suitable buds, later migrants formed big buds as readily as do earlier migrants.

Apparently a considerable time elapses between the first entry into the new bud and resumption of egg laying. Smith (134) first observed eggs approximately six weeks after the first entry into the new buds. He suggested (133) that this delay might be due to unfavorable nutritional conditions existing during the period of flower bud initiation.

During the summer, the mites reproduce in the new buds and these buds grow considerably during July and August. By October, a peak population averaging 4000 mites per gall is attained. Oviposition declines rapidly until, from late November through December, no eggs are laid (21). Smith (134) estimated that at least six generations per year are produced.

\section{Mite-Virus-Host Relationships}

A correlation between the incidence of big bud and reversion-or "going wild" as it was sometimes called-was noted by Lees in 1917 (63) ; however, he thought that some reversion was caused by a factor or factors unrelated to big bud since he observed that not all reverted bushes had big buds. In 1925, Lees (65) reportedly transmitted reversion to one of eight plants by grafting and concluded that since he found no microorganisms associated with the disease a virus must be the cause.

Amos et al. (2) initiated studies on transmission of reversion in 1921. They transferred $C$. ribis to one branch of a two-branched black currant bush and attempted to isolate the branches from each other. Reversion symptoms and.mite-infested big buds developed on both branches. They also performed rather extensive grafting experiments and showed a positive correlation between the presence of big bud and reversion on plants, and a lack of positive correlation between the number of big buds and the degree of reversion. These workers were unable to demonstrate seed transmission or sap transmission of reversion.

Several years later, Massee (69) transferred large numbers of $C$. ribis from reverted bushes to each of 24 healthy black currant bushes over a two-year period. Six healthy plants received no mites. Colonies were established on the 24 test plants during the first year, and each of these plants developed reversion symptoms in three years or less. The six check plants showed no symptoms of reversion. Massee concluded that $C$. ribis "can be regarded as a vector of reversion."

Unfortunately, Massee's work was hardly more indicative of virus trans- 
mission than of injection of a phytotoxin by $C$. ribis. Also, the work reported earlier by Amos et al. (2) did not conclusively show that reversion is graft-transmissible since they apparently made no attempt to control $C$. ribis. The apparent graft transmission could have been nothing more than phytotoxic effects of $C$. ribis that had moved from scion to stock or vice versa.

Proof that $C$. ribis transmits a virus causing reversion was difficult to obtain owing to several factors. First, $C$. ribis feeds in terminal and axillary buds. As a result of feeding, developing of flowers is often prevented and leaves issuing from terminal buds exhibit an abnormality that resembles reversion and probably has been confused with reversion in the past (146). Also, as indicated by Massee (69), two to three years may elapse before symptoms of reversion appear. Recently, Thresh (151) pointed out that there have been few attempts to find a suitable indicator plant for reversion, yet an indicator is essential for diagnosis and to distinguish the effects of reversion virus from those of the vector and other viruses.

Severa1 recent studies have contributed to a substantiation of earlier reports that $C$. ribis transmitted a virus that caused reversion. Smith (135) transferred 1,5 , or $20 C$. ribis to each of several healthy black currant plants then fumigated them to kill the mites. Only a few plants developed populations, and these apparently were limited to buds close to the point where mites were introduced. Some populations were initiated with a single mite. After two years, 46 per cent of the plants cxhibited typical symptoms of reversion.

Thresh (145) reported what must be considered the most conclusive evidence that $C$. ribis transmits a virus which causes reversion. Thresh transferred $C$. ribis from plants that exhibited symptoms of reversion or vein pattern (an early symptom of reversion) to healthy black currant seedlings and then dipped the seedlings in 0.05 per cent endrin after four days to destroy the mites. No live mites were found in subsequent observations. Within a month, vein pattern appeared on the seedlings. At this point, Thresh grafted patches of bark of the seedlings to healthy black currants. These plants subsequently showed symptoms of reversion but check plants did not.

Both Smith (136) and Thresh (150) conducted field experiments which showed natural spread of $C$, ribis and reversion. Smith showed that both mites and reversion spread along rows much more readily than across rows. Apterous and alate currant aphids (Hyperomyzus lactucae) were important in spreading the mites. Thresh demonstrated that $C$. ribis and reversion spread predominantly in the direction of winds prevailing during the mite's dispersal season. Thresh stated that more bushes developed galls than later produced symptoms of reversion. In both healthy and virus-infected bushes, the incidence of galls decreased with increasing distance from the source.

In the course of studies of $C$. ribis and its relation to reversion, certain workers suggested that reverted bushes were more susceptible than healthy 
bushes to attack by $C$. ribis since big buds occurred almost exclusively on reverted bushes, and big buds were seldom observed prior to symptoms of reversion $(64,65,143)$. Thresh's recent studies $(147,148,151)$ of the spread of $C$. ribis in the field plots showed rather conclusively that reverted bushes were many times more susceptible to infestation by $C$. ribis than were healthy bushes. Also, Thresh reported differences in susceptibility among varieties of healthy black currants and greater susceptibility in plants infested with a virulent strain of reversion than in plants infected with a mild strain of reversion. He largely attributed the degrees of susceptibility of the plants to the relative densities of epidermal hairs that impeded the movement of dispersing mites. Numerous hairs developed early in the growth of leaves and stems of healthy bushes; however, hairs were quite sparse on reverted bushes. Differences in susceptibility among varieties and between plants infected with different strains could be accounted for similarly. Thresh considered that infection with reversion caused an increase in the proportion of susceptible buds by decreasing the density of hairs on leaves developing around shoot apices. Thresh further pointed out that the increased susceptibility to infestation by $C$. ribis was due to the specific anatomical changes resulting from virus infection and not just to the presence of virus, since bushes with reversion symptoms on one part of the plant only developed much higher infestations on those branches than on those without symptoms. This increased susceptibility is indeed interesting, inasmuch as it represents a mutually advantageous relationship between the vector-mite and the virus it transmits.

\section{CONTROL OF Vector AND Virus}

Thresh's work indicated that control of $C$. ribis depended upon control of reversion and vice versa. Slykhuis (128) reviewed the subject of acaricidal control of $C$. ribis. Roguing of infected black currant bushes in conjuction with chemical control of $C$. ribis is the standard practice in England. Chemical applications are intended to kill the mites during the spring migration period.

Recently, Smith \& Corke (137) reported control of C. ribis using (2chloroethyl) trimethyl ammonium chloride, a plant growth retardant. This gave control comparable to that resulting from accepted applications of endosulfan. According to the authors, the growth retardant had no direct toxic effect on the mites but altered the habit of the plant and made it more resistant to successful colonization by the mite.

Certain investigators have used extreme temperatures to control $C$. ribis or reversion virus, or both. Taksda (144) studied cold hardiness in populations of $C$. ribis from eastern Norway, western Norway, and England and found marked differences in the ability to produce eggs at $6^{\circ} \mathrm{C}$ and the ability to survive at $-18.5^{\circ} \mathrm{C}$. The degree of cold hardiness was greatest in the populations from the coldest area and least in the population from the warmest area, where this characteristic would be of least survival value. 
Cold treatment of infested cuttings was not recommended for the Norwegian populations since temperatures that killed mites also damaged the cuttings. In the English population, there appeared to be a reasonable safety margin between the lethal temperature for mites and that causing damage to the cuttings.

Thresh (149) used warm water treatments to eliminate C. ribis infestations of dormant black currant cuttings. Effective treatments did not affect subsequent growth of the cuttings. Apparently, both mites and eggs were destroyed. Campbell (19) succeeded in obtaining reversion-free clones of black currants by exposing infected bushes to hot air $\left(34^{\circ} \mathrm{C}\right)$ and grafting the soft apex of shoots $(1 \mathrm{~cm}$ long) to currant seedlings. The heat treatment masked symptoms of reversion on infected bushes only temporarily, but apparently the virus was destroyed in the apices since bushes resulting from the grafts remained healthy.

In still another approach to control of reversion, Tiits (152) attempted to graft-inoculate various varieties of black currant, hybrids, and other Ribes spp. and concluded that reversion was limited to black currant. $\mathrm{He}$ suggested breeding reversion-resistant varieties by crossing black currants with other Ribes spp.

\section{FIG MOSAIC}

Fig mosaic diseasc was studied first in California by Condit \& Horne (22). Apparently, these investigators immediately suspected that Aceria ficus, an eriophyid that was widespread on figs in California, might cause the disease itself or transmit a virus that caused the discase. Although they recognized that the disease might be the direct result of feeding by $A$. ficus on young, tender leaves, they also found figs in Oregon that were heavily infested with $A$. ficus but which had deep green foliage.

In greenhouse tests, they rooted 100 cuttings from plants showing mosaic and observed that 74 developed mosaic symptoms. In contrast, when they grew trecs from seeds of trees that showed mosaic symptoms, the seedlings showed no symptoms of mosaic. They performed graft-transmission tests, but since the trees were infested with mites the resulting appearance of symptoms of mosaic could hardly be considered proof of graft-transmisision of a causative virus. Also, they infested two healthy fig seedlings with $A$. ficus, and both seedlings developed mosaic symptoms. Unfortunately, they did not attempt to confirm transmission by destroying the mites and graftinoculating healthy trees from the seedlings.

Although $A$. ficus was considered the probable vector of a virus causing fig mosaic (43), no proof was provided until 1955. According to Flock \& Wallace (34), in 1944 Wallace performed tests similar to those of Condit \& Horne (22) in which eriophyid mite-infested bud scales from field trees were placed on small fig seedlings. Several of the seedlings developed mosaic symptoms, but no attempt was made to destroy the mites; consequently, the possibility of direct feeding injury remained. Then, in 1955, Flock \& 
Wallace (34) demonstrated that mosaic symptoms persisted on figs in the absence of $A$. ficus by treating infested cuttings with sulphur to kill the mites, rooting the seedlings, and observing the development of mosaic symptoms on new growth. Also, they successfully graft-inoculated healthy fig seedlings by implanting diseased, mite-free plant tissue, and thus showed that fig mosaic was, indeed, caused by a transmissible virus. Having established that fig mosaic virus was transmissible by grafting, they transferred various numbers of $A$. ficus from fig trees infected with mosaic to healthy seedlings that were kept in mite-free cages. After three to five days the plants were dusted with sulphur to eliminate the mites. $A$. ficus proved to be an efficient vector. Seven of ten plants that received one mite developed fig mosaic. Higher percentages of infection resulted when greater numbers of mites were used. Flock \& Wallace recognized that feeding injury by $A$. ficus might cause early symptoms that could be confused with symptoms of infection by the virus. To differentiate between the two, they established a virusfree colony of $A$. ficus by transferring eggs to healthy seedlings. Then they transferred virus-free mites to one group of healthy seedlings and infective mites to another group and compared the symptoms that appeared on the two groups. The virus-free mites caused leaf distortion, chlorosis, and russeting, but these symptoms were distinguishable from symptoms of mosaic that appeared on the group that received infective mites. This experiment also showed that fig mosaic virus was not transmitted through the egg of $A$. ficus. Also, according to Blodgett \& Gomec (9) the virus is not transmitted through the seed or by sap inoculation.

Fig mosaic virus has been reported only from the family Moraceae. Condit \& Horne (22) listed four Ficus spp. as hosts. Burnett $(17,18)$ added 13 more Ficus spp. and Cudranea tricuspidata to the host list. Vashisth \& Nagaich (157) showed that it also infected mulberry, Morus indica. These investigators also cited unpublished experiments in which they transmitted fig mosaic virus using $A$. ficus. This apparently is the only confirmation of Flock \& Wallace's incrimination of $A$. ficus as the vector.

Fig mosaic is quite likely present in all countries where figs are grown. It has been reported from countries on every continent except South America (9). According to Condit \& Horne (22), the vector is widespread in California and also occurs in Oregon. A. ficus has also been reported from Italy (43) and India (157). It seems likely that this mite will be found in most areas where figs are grown.

The life history of $A$. ficus was studied by Baker in California (7). He reported that all stages and both sexes were found throughout the year. Mites spent the dormant season in buds and were exposed as the buds burst in the spring. Following bud burst, eggs were laid on the stems and on both surfaces of the leaves, although as the leaves matured a greater proportion of eggs were laid on the lower leaf surface. During July, many mites left the leaves and entcred the fruits. In addition to transmitting fig mosaic virus, $A$. ficus feeds on leaves and kills epidermal cells (7). Also, it causes 
russeting and scarring of the eye scales and seeds of the fruit and it occasionally causes stunting of twigs and immature-leaf drop (30).

\section{PEACH MOSAIC}

This disease was first recognized in Texas and Colorado. It is now known to occur also in southern California, southern Utah, Arizona, New Mexico, southern Oklahoma, western Arkansas, and Mexico (48).

\section{The VIRUS}

Although peach mosaic virus is readily transmitted by grafting, it is not sap-transmissible (48) and attempts to purify it have been unsuccessful (96). Its host range is limited to certain species of the genus Prunus (48). All of the 209 peach varieties tested by Cochran \& Pine were susceptible (20). Of these, most clingstone varieties showed only slight symptoms, but most freestone varieties showed definite symptoms. Forty-two of 43 horticultural varieties of plum tested by Pine \& Cochran were susceptible (97). Also, nectarines, almonds, and apricots are susceptible. Several other species of Prunus have been experimentally infected $(20,48)$. On the other hand, cherries ( $P$. avium, $P$. cerasus, and $P$. mahaleb) are immune $(20,48)$.

In Texas, wild $P$. angustifolia is an important reservoir of the virus (48). In New Mexico, Arizona, and Utah, P. munsoniana, planted along irrigation canals, is often infected (48). In addition to these two species, three other species native to areas east of the Rocky Mountains $P$. americana, $P$. mexicana, and $P$. hortulana, are also susceptible (20). In contrast, Cochran \& Pine (20) tested six Prunus species native to western North America and found that only $P$. subcordata (Sierra plum) was susceptible.

\section{THE VeCTOR}

In the case of currant reversion and fig mosaic, certain eriophyids were suspected of being vectors many years before their role as vector was proven. While this was not the case with the eriophyid species that transmit grass viruses, nevertheless, these species were described before their vector capabilities were demonstrated.

In the case of peach mosaic, the discovery of Eriophyes insidiosus was the result of the search for a vector of the virus. This species was first found in retarded buds of mosaic-infected peach trees by Wilson in 1955, and within a few months of its discovery, Wilson et al. (166) demonstrated its ability to transmit the virus. Keifer \& Wilson (60) described it shortly after it was shown to be a vector.

On most commercial peach varieties, E. insidiosus is usually limited to retarded adventitious buds found near the base of large scaffold branches. They cause considerable cell hypertrophy in these buds as well as in buds of all their other known hosts (165). On wild plums ( $P$. hortulana, $P$. mexicana, and $P$. angustifolia), and on some flowering peaches, they occasionally are found unprotected on petioles and green stem tissue near leaf axils as 
well as in buds; however, on commercial peach varieties they have been found only inside retarded buds. On wild plums and flowering peaches, they infest axillary buds and are thus more generally dispersed on the host plant (165).

In southern California, reproduction occurs on peach throughout the year, but it is quite low during the winter. From March to May, populations increase rapidly and then remain high in retarded buds throughout the summer. Usually, by October, the buds die and the mites either leave or die (165). Little direct information on migration is available; however, Jones \& Wilson (49) showed that when groups of healthy potted peach trees wcre exposed in a peach-mosaic infected orchard for 2-month periods from March to October, natural spread of the virus occurred as early as April and continued at least September. Presumably, E. insidiosus left the buds throughout this period.

Prior to the discovery of $E$. insidiosus, another eriophyid mite, Aculus cornutus (the peach silver mite), had been shown to be incapable of transmitting peach mosaic virus. After $E$. insidiosus was discovered and incriminated as a vector, Eriophyes prunandersoni, a species that closely resembles $E$. insidiosus, came under close scrutiny. Although $E$. prunandersoni causes erinea on leaves of $P$. andersoni, $P$. fasciculata, and $P$. fremontii-three xerophytic species native to western North America-attempts to rear it on peach and $P$. hortulana failed. Also, attempts to rear $E$. insidiosis on $P$. andersoni and $P$. fremontii failed. Perhaps more significantly, in mixed plots, $E$. insidiosus developed heavy populations on $P$. hortulana, P. mexicana, and peach in one growing season, but failed to develop detectable populations on $P$. andersoni or P. fremontii over a six-year period (165).

Several other Prunus species are hosts of Eriophyes spp. that are closely related to $E$. insidiosus. Keifer $(55,58)$ described two species from $P$. subcordata, the only native western North American species that is known to be susceptible to the peach mosaic virus. At present, it is unknown whether these species are capable of transmitting the virus.

The discovery of $E$. insidiosus led to a survey of peach orchard environs in southern California where none of the early recognized Prunus hosts of E. insidiosus occurred naturally. Several new species of Eriophyidae have been found as a result of the survey; however, $E$. insidiosus has not been found on any additional plant species (165).

The known host range of $E$. insidiosus includes many varieties of commercial and flowering peaches as well as $P$. cerasifera, $P$. simonii, $P$. hortulana, $P$. munsoniana, $P$. mexicana, and $P$. angustifolia. The latter four species are native to southeastern United States and, as mentioned earlier, two of them are reservoirs of peach mosaic virus as well as E. insidiosus in certain south central states west of the Mississippi River (165).

Since $1955, E$. insidiosus has been found in several other states. To date, it has been found in western Colorado, Arizona, New Mexico, Texas, Ar- 
kansas, and Utah. Also, it has been collected from $P$. angustifolia outside the range of peach mosaic virus in Mississippi and Georgia. Efforts to find it in Illinois, Maryland, Missouri, Louisiana, and Wisconsin have failed (165).

Until recently, in California, E. insidiosus was known to occur only south of the Tehachapi Mountains; however, it is now found on flowering peaches in a few locations in the San Joaquin Valley. In spite of concerted efforts by state and federal agencies to find $E$. insidiosus in commercial varieties of peaches in the San Joaquin Valley, it is still unknown except on flowering peaches. Also, the virus is not known to occur in that area (165).

\section{Mite-Virus Relationships}

In the studies in which Wilson et al. (166) showed that E. insidiosus transmitted peach mosaic virus, they reported transferring several mites from infected peach to each of several small Rio Oso Gem peach seedlings. Several of the seedlings developed typical symptoms of peach mosaic. They also transferred $E$. insidiosus from healthy peach trees to seedlings, but no symptoms of mosaic appeared on any of the latter group. To further check that mites from the infected trees had actually transmitted a virus, they grafted pieces of bark from the several seedlings showing symptoms to other healthy Rio Oso Gem seedlings. The appearance of symptoms on all of the latter plants showed conclusively that $E$. insidiosus had, in fact, transmitted a virus causing peach mosaic.

Subsequent tests in which single adults were transferred to each of 80 plants resulted in two cases of transmission. When two to ten mites were transferred to each healthy plant, 11 of 56 plants became infected. When 50 or more mites were transferred to each plant, 18 of 25 plants became infected. In all, several hundred plants have been experimentally inoculated with peach mosaic virus using $E$. insidiosus from sources in southern California and New Mexico (165).

Wilson \& Jones (165) transferred approximately 5400 eggs to 28 healthy peach plants and allowed the mites to hatch and feed. The lack of any cases of transmission indicated that the virus was not transmitted through the egg of the vector. $E$. insidiosus was shown to be able to transmit the peach mosaic virus from peach to peach, apricot and $P$. mexicana, from $P$. mexicana to peach, and from $P$. hortulana to peach. Although $E$. insidiosus can transmit the virus to apricot, it does not reproduce on apricot (165).

Several of the details of transmission have, as yet, eluded discovery owing to exceptional technical difficulties in rearing and manipulating the vector. Nevertheless, by holding infective mites on glass slides and then transferring them to healthy plants and effecting transmission, Wilson \& Jones showed that the virus persisted in the vector for at least 48 hours (165). 
In order to perform critical vector tests on eriophyid-transmitted viruses, it is necessary to have adequate laboratory or greenhouse cultures of the vector. This has been difficult to attain with $E$. insidiosus; however, a recent technique used by Oldfield \& Wilson (90) may facilitate the rearing of large numbers of $E$. insidiosus in the greenhouse. They established greenhouse cultures of $E$. insidiosus by inducing root formation on infested flowering peach cuttings and then planting them.

\section{Control of Vector and Virus}

In southern California, control of the spread of peach mosaic has involved systematic surveying of peach orchards and removal of infected trees. Jones et al. (51) recently concluded an experiment in which they attempted to evaluate the effectiveness of chemical control of $E$. insidiosus as a means of controlling the spread of the virus. Each spring, for five successive years, a single treatment of diazinon was applied at petal fall to each of several peach orchards in which peach mosaic was spreading rapidly.

Over 100 new cases of peach mosaic appeared in one year after the first treatment. The number of new cases decreased to 46 the second year. For the next five years, there were never more than two new cases per year. Based on known cases of spread in other southern California areas, the authors concluded that spread of the virus had been significantly arrested by controlling the vector.

\section{CHERRY MOTTLE LEAF}

This disease was first reported from Oregon in 1920 and its virus nature was established in 1935. It occurs in sweet cherry-growing districts of Washington, Oregon, Idaho, California, and British Columbia. In Washington, it is most often found in foothill or canyon orchards, often in close association with wild bitter cherry, Prunus emarginata (76).

In 1958, L. S. Jones found a $n$ unidentified species of eriophyid in abnormally enlarged buds of $P$. emarginata bordering commercial cherry orchards near Wenatchee, Washington. This species was later described and named Eriophyes inaequalis by Wilson \& Oldfield (167).

Later, $E$. inaequalis was found in the vicinity of wild $P$. emarginata in a few buds of commercial cherries that were infected with mottle leaf virus (50). Still later, Jones et al. (50) showed that E. inaequalis transmitted the cherry mottle leaf virus. $P$. emarginata was found to be the principle host of the mite and a common reservoir of the virus.

In the initial series of tests, Jones et al. transferred $50 \mathrm{E}$. inaequalis from mottle leaf-infected $P$. emarginata to each of 20 newly germinated peach seedlings. Since peach is not a host of $E$. inaequalis and is a symptomless carrier of cherry mottle leaf virus, buds from each of the 20 peach trees were grafted to healthy potted Bing cherry trees in the following spring. Typical cherry mottle leaf symptoms developed on 12 of the Bing cherry 
trees. Subsequent tests corroborated these findings. Also, in 1968, Wilson \& Oldfield (168) transferred $E$. inaequalis from mottle leaf-infected $P$. cmarginata to each of 13 Bing cherry trees. Apparent symptoms of mottle leaf developed on eight of these plants but not on any of the check plants that received no mites. Verification of these results by graft transmission to other healthy Bing cherries is in progress at the time of this writing.

\section{ROSE ROSETTE}

Recently, Allington et al. (1) reported that they had transmitted rose rosette virus in Nebraska with Phyllocoptes fructiphilus Koch. (The correct name is Phyllocoptes fructiphilus Keifer 1940.) In one series of tests, ten $P$. fructiphilus from infected wild rose were transferred to each of ten healthy Rosa eglanteria. According to the authors, five plants became infected with rose rosette virus. The authors state that several species of Rosa were proved to be infected with rose rosette virus "either by grafting or by mite transmission"; however, they did not specifically state that the virus was graft-transmitted from those test plants to which P. fructiphilus had been transferred. This may only be an error of omission. Unless they graft-transmitted a virus from the plants that received mites, the appearance of symptoms on plants to which $P$. fructiphilus was transferred could be attributed to a mite-induced toxemia that resembled rose rosette. A definite statement that both types of transmission were accomplished in sequence would greatly substantiate their claim of transmission of a virus by $P$. fructiphilus. Also, a comparison of the effects on healthy rose plants of populations from infected and healthy roses would further substantiate their case.

Recently, Keifer (59) described Phyllocoptes slinkardensis from a wild species of rose in Mono County, California. He stated that slinkardensis "was extremely close to fructiphilus" except for the shape of the microtubercles. Also, he said that the mites were collected from roses showing witch's broom and "grafting tests have shown that this broom is virus induced and the Phyllocoptes, which was found on the native rose, could be the vector." The relationship between $P$. fructiphilus and $P$. slinkardensis probably should be investigated.

\section{A LATENT VIRUS OF PLUM}

In 1966, Proeseler \& Kegler (101) reported that Aculus fockeui transmitted a latent virus of plum trees from plum to Chenopodium foetidum. Generally, the mites perished within 24 hours after being transferred to Chenopodium. Local lesions developed on the leaves after seven to ten days. Juice inoculations from these plants to other $C$. foetidum and to $C$. quinoa resulted in the appearance of local lesions on the inoculated plants. Proeseler \& Kegler found particles about $750 \mathrm{~m} \mu$ long in preparations from Chenopodium leaves to which mites had been transferred and which subsequently showed lesions, and from Chenopodium leaves that had been juice-inocu- 
lated. They concluded that these particles were the virus that the mites transmitted.

\section{PIGEON PEA STERILITY}

In 1963, Seth (108) conducted transmission tests of pigeon pea sterility virus with aphids, leafhoppers, whiteflies, and two unidentified mite species but failed to get positive results. However, a third mite, an eriophyid, reportedly transmitted the virus. In one test he transferred healthy pigeon pea leaves with eriophyids to one group of healthy plants, and diseased pigeon pea leaves also with eriophyids to another group of healthy plants. In a second test, he transferred 5 to 20 eriophyids from healthy plants to one group of healthy plants and 5 to 20 eriophyids from diseased plants to a second group of healthy plants. After five days, the plants were sprayed regularly with a pesticide to kill the mites. None of the 53 plants in the two groups that received mites from healthy pigeon pea became diseased. Seven of 30 plants that received diseased pigeon pea leaves with eriophyids showed sterility symptoms. Four of 24 plants that received eriophyids from diseased plants showed sterility symptoms. Seth concluded that the eriophyids had transmitted sterility virus.

Although Seth included a photomicrograph of one eriophyid and stated that he found them buried between the hairs on the undersurface of the leaves, there is no evidence that he used just one species of eriophyid and he apparently did not identify the species. The demonstration of graft transmission of the virus from plants inoculated by the mites would greatly strengthen Seth's claim of transmission by eriophyids.

No studies corroborating Seth's work have yet been published. In 1965, Narayanasamy \& Ramakrishnan (82) reported negative results in attempts to transmit sterility virus using certain aphids, leafhoppers, and "an eriophyid mite, Tetranychus sp." Obviously, from this statement we cannot be sure that they used an eriophyid mite. Also, these workers offered evidence which suggested that nematodes or other soil-borne organisms transmitted the sterility virus.

\section{MANGO MALFORMATION}

This disease is characterized by the transformation of the inflorescence into a compact mass of sterile flowers in adult trees and production of numerous vegetative shoots at the growing point or in the axil of the leaf in the case of seedlings (83).

No adequately controlled vector tests using eriophyids have been reported for this disease; however, Nariani \& Seth (83) pinned eriophyid-infestcd bud scales taken from diseased and apparently healthy plants on mango seedlings and found that seedlings that received bud scales from either source later developed symptoms of malformation. In a later paper, these authors (109) reported on methyl bromide fumigation of mango seedlings affected 
with malformation and commented that feeding by Aceria mangiferae caused malformation.

Other recent reports reviewed the status of this disease and cast some doubt on the role of Aceria mangiferae as the direct cause of the disease. Prasad et al. (99) were unable to find any correlation between populations of $A$. mangiferae and the degree of malformation, and they concluded that the disease was not the result of direct feeding injury by the mite. They were also unable to transmit the disease by budding or grafting and were thus unable to suggest a viral nature of the disease. Then, Ginai (41) suggested that malformation was caused by a virus that is spread by "mites and other insects as vectors," but he offered no experimental evidence to support his contention. More recently, Rai \& Singh (103) reported recovery from malformation in mango saplings treated with 0.1 per cent Diazinon to kill $A$. mangiferae. This evidence favors a hypothesis that $A$. mangiferae causes malformation; however, critical tests are obviously necessary to clarify the role of $A$. mangiferae in malformation disease.

\section{AGROPYRON MOSAIC}

Agropyron mosaic virus has been reported from $A$.repens in the United States and Canada (128). Staples \& Brakke (141) reported that this entity was indistinguishable from WSMV on the basis of particle size, sedimentation rate, and stability toward selective denaturation procedures, but had a slightly different host range than WSMV. Later, Slykhuis (128) cited unpublished tests which showed other important differences between these entities. Also, Slykhuis observed that wheat seedlings became infected with Agropyron mosaic virus when they were grown in pots covered with cages made of 72-mesh per inch screen and exposed in the field near naturally infected $A$. repens. This suggested that a very small vector was involved, but Slykhuis's tests with eriophyids were inconclusive.

\section{GRAPEVINE PANASCHURE}

Ochs (86-88) reported that Eriophyes vitis and several insects transmitted a virus that reportedly caused panaschure of vines in Germany. Ochs claimed that she was able to sap-transmit the virus to several herbaceous plants; however, she offered practically no experimental evidence for mite transmission. Niemeyer \& Bode (85) refuted the above claims after extensive attempts failed to duplicate her sap inoculations of herbaceous plants. Until more convincing evidence is reported, this must remain a doubtful case of transmission by an eriophyid mite.

\section{CADANG CADANG}

Cadang cadang is a degenerative disease of coconut palms which is widespread in the Philippines. A virus is suspected to be the causative agent (128). The pattern of spread of cadang cadang led Briones \& Sill (14) to 
consider eriophyids as vector suspects; however, vector tests with four species from coconut palms were negative. Nevertheless, according to Bigornia (8), eriophyids are continuing to receive attention as possible vectors of a causative virus of this disease.

\section{CONCENTRIC RING BLOTCH OF CITRUS}

In 1958, Dippenaar (28) reviewed the history of this disease in South Africa and gave experimental evidence to indicate that it was caused by the feeding of Calacarus citrifolii. However, in 1963, Rossouw \& Smith (106) performed tests with what reportedly was $C$. citrifolii and maintained that C. citrifolii transmitted a virus causing the disease. Their conclusion was largely based on tests in which they transferred mites from diseased and healthy plants to different groups of healthy rough lemon seedlings. Those that received mites from healthy plants did not develop symptoms of concentric ring blotch, but those that received mites from diseased plants did develop symptoms. Rossouw \& Smith did not state what measures were taken to identify mites from the various sources and they did not state whether they had obtained transmission by grafting or sap inoculation. Also, they stated that the symptoms appeared only on the localized spots where the mites were confined. No subsequent corroborative reports have appeared, but a later report by Van der Merwe \& Coates (155) on the biology of $C$. citrifolii failed to mention Rossouw and Smith's work. Instead, they noted that Dippenaar had demonstrated that $C$. citrifolii was the cause of concentric ring blotch.

\section{PLANT VIRUS TRANSMISSION BY TETRANYCHID MITES}

Slykhuis (128) cited several reports of suspected virus transmission by tetranychids; however, in most cases little or no experimental evidence is offered.

In 1963, Schulz (107) reported successful transmission of potato virus $Y$ (PVY) by Tetranychus telarius (L.) [ $\doteq$ T. urticae Koch (154)]. The highest rate of transmission was obtained when mites were given a 5-minute acquisition-feeding period followed by a 5 -minute transmission-feeding period. In this case, 12 of 32 test plants developed symptoms of infection with potato virus $\mathrm{Y}$. Mechanical inoculations from the test plants confirmed the presence of the virus.

Recent reports by Fritzsche et al. (36) and Orlob (94) failed to confirm Schulz's work, but elucidated some interesting relationships between $T$. urticae and several plant viruses including potato virus $Y$. Beside being unable to demonstrate transmission of PVY by the method employed by Schulz, Fritzsche et al. were unable to transmit PVY by rubbing leaves with homogenates of mites that had fed on PVY-infected plants. They also attempted to inoculate healthy plants with PVY by rubbing the leaves with feces of mites that had fed on infected plants. This also failed. Neither Fritzsche et al. nor 
Orlob were able to detect PVY particles in electron micrographs of homogenates of mites that had fed on PVY-infected plants.

Orlob was also unable to demonstrate transmission of eight other plant viruses by $T$. urticae although he demonstrated by bioassay, electron microscopy, or serology, or all three methods, that tobacco mosaic virus, potato virus $\mathrm{X}$, onion yellow dwarf virus, and tomato bushy stunt virus were in the mites that fed on plants infected with these viruses. Orlob showed that TMV could be acquired in 10 seconds and most mites acquired it within a 16-hour acquisition-feeding period. Feces were infectious, but feeding and moving by mites did not result in infection of the plant. On the other hand, mites were able to inoculate either TMV or PVX sprayed onto the leaf surface. The results of Fritzsche et al. generally agreed with or complemented Orlob's results using TMV. Although mites did not transmit TMV, Fritzsche and colleagues found that the virus was recovered from healthy plants upon which mites from TMV-infected plants had fed. This was accomplished by successfully inoculating healthy plants with macerates of the plants to which the mites were transferred. Fritzsche et al. found TMV particles in electron micrographs of macerates and feces of mites that had fed on TMV-infected plants. As Orlob had, they, too, found that mites were able to inoculate plants with TMV that was sprayed onto the leaves. Orlob summarized the results as providing an example of the failure of a mite to transmit plant viruses in the absence of immediate obvious reasons why it should fail to do so.

In spite of two rather extensive studies of the relationships between $T$. urticae and several plant viruses including potato virus $\mathrm{Y}$, Schulz's report remains uncorroborated at this time.

\section{CONCLUDING REMARKS}

Other than wheat streak mosaic virus and $A$. tulipae, few specific relationships between eriophyid mites and the viruses they trasmit have been elucidated. I have mentioned some reasons for the paucity of information in certain cases. Certainly, the size of eriophyids and their ability to cause virus-like symptoms by their feeding activities have, in many cases, slowed progress toward discovering many of these relationships. Nevertheless, we can make ccrtain generalizations at this time, although perhaps some will be invalidated as more information regarding eriophyid transmission becomes available.

The available evidence points to a high degree of specificity between vector eriophyids and the viruses they transmit. As yet, no virus is known to be transmitted by more than one eriophyid species, and there is no substantiated case of transmission of any of the eriophyid-borne viruses by any other taxonomic group. As far as is known, only one eriophyid species, $A$. tulpiae, transmits more than one virus and there appears to be reason to suspect that the two viruses (WSMV and wheat spot mosaic virus) might be 
related. As yet, only these two viruses have been shown to be transmitted by A. tulipae, although mites currently considered to be $A$. tulipae occur on many monocotyledenous species, the total number of which are affected by many viruses.

In the two cases studied (WSMV and peach mosaic virus), the virus persists in the vector for at least a few days. Also, no case of transovarial transmission in the mite has been reported. In fact, in several instances virus-free colonies are commonly established by transferring eggs of infective mites to healthy, mite-free plants. This technique has been used successfully in vector studies of WSMV, wheat spot mosaic virus, ryegrass mosaic virus, peach mosaic virus, and fig mosaic virus.

Keifer (57) recently designated the long-recognized family Eriophyidae as superfamily Eriophyoidea and included three families: Rhyncaphytoptidae, Phytoptidac, and a more restricted Eriophyidae. The proven vector species of eriophyids all belong to Eriophyidae in the restricted sense. One of the other two families (Phytotidae) is largely restricted to conifers. The other family (Rhyncaphytoptidae) includes only species that are free-living on leaves. This may be a reason for the absence of any reported vectors in this family since most of the well-studied cases of transmission by eriophyids involve species that are relatively intimately associated with their hosts. Transmission of ryegrass mosaic virus by $A$. hystrix is an exception; $A$. hystrix is a rust mite. $A$. fockeni, reportedly a vector of a latent virus of plum, is also a rust mite.

The correct identification of eriophyids used in vector studies is of paramount importance. Since often more than one species live on the same plant, the establishment of pure colonies is a prerequisite to any critical study. Periodic sampling of colonies for identification is also important.

At present, $A$. fockeni, the species recently reported as a vector of a latent virus of plum, is the only reported vector in which the diapausing deuterogynous generation is known to occur in its life cycle. An investigation of retention of the virus through the deutogyne stage might be a valuable addition to the knowledge of mite-virus relationships.

Wheat streak mosaic virus particles and ryegrass mosaic virus particles are about $700 \mathrm{~m} \mu$. long. The oral opening of eriophyids appears to be somewhat less than one $\mu(1000 \mathrm{~m} \mu)$ in diameter (perhaps $1 / 2 \mu$ ). The relative sizes of virus particle and oral opening are such that particlcs may not be able to enter if they are oriented with the long axis across the oral opening.

In most of the substantiated cases of transmission by eriophyids, virus infection results in the appearance of irregular chlorotic areas on the leaves. This condition is usually called "mosaic." In this group are included wheat streak mosaic, wheat spot mosaic, ryegrass mosaic, fig mosaic, peach mosaic, and cherry mottle leaf. The best known symptoms of currant reversion constitute an exception; however, according to Thresh (145), even currant reversion includes a "vein pattern" on leaves as an early symptom. Appar- 
ently, some of the diseases that have been recently reported as caused by eriophyid-borne viruses exhibit quite different symptoms.

From the reports by various investigators, it is obvious that there are several reports of virus transmission by eriophyids that need much substantiative work. Similarly, the case of transmission of potato virus $Y$ by $T$. ur ticae needs corroboration.

Eriophyids have been shown to be capable of transmitting viruses of monocots and viruses of dicots. Undoubtedly, they will continue to command attention as vector candidates. 


\section{LITERATURE CITED}

1. Allington, W. B., Staples, R., Viehmeyer, G. Transmission of rose rosette virus by the eriophyid mite Phyllocoptes fructiphilus. J. Econ. Entomol., 61, 1137-40 (1968)

2. Amos, J., Hatton, R. G., Knight, R. C., Massee, A. M. Experiments in the transmission of reversion of black currants. Ann. Rept. East Malling Res. Sta., Kent, 1925, II Suppl., 126-50 (1927)

3. Arnott, D. A., Berges, I. Causal agents of silver top and other types of damage to grass seed crops. Can. Entomologist, 99, 66070 (1967)

4. Ashworth, L. J., Futrell, M. C. Sources, transmission, symptomatology and distribution of wheat streak mosaic virus in Texas. Plant Disease Reptr., 45, 220-24 (1961)

5. Atkinson, D. E. Western wheat mosaic in Colorado and its transmission by the grain aphid Toxoptera gramineum. Fhytopathology, 39, 2 (1949)

6. Atkinson, T. G., Slykhuis, J. T. Relation of spring drought, summer rains and high fall temperatures to the wheat mosaic epiphytotic in southern Alberta. Can. Plant Disease Surv., 43, 154-59 (1963)

7. Baker, E. W. The fig mite, Eriophyes ficus Cotte and other mites of the fig tree (Ficus carica L.). Bull. Calif. Dept. Agr., 28, 266 75 (1939)

8. Bigornia, A. E. (Personal communication, 1969)

9. Blodgett, E. C., Gomec, B. Fig mosaic. Plant Disease Reptr., 51, 893-96 (1967)

10. Boczek, J. Studies on mites (Acarina) living in Poland. VIII. Bull. Acad. Polon. Sci., Sér. Sci. Biol., 16, 631-36 (1968)

11. Brakke, M. K. Properties, assay and purification of wheat streak mosaic virus. Phytopathology, 48, 439-45 (1958)

12. Brakke, M. K., Staples, R. Correlation of rod length with infectivity of wheat streak mosaic virus. Virology, 6, 14-26 (1958)

13. Brandes, J., Wetter, C. Classification of elongated plant viruses on the basis of particle morphology. Virology, 8, 99-115 (1959)

14. Briones, M. L., Sill, W. H. Habitat, gross morphology and geographical distribution of four new species of eriophyid mites from coconuts in the Philippines. Food Agr. Organ., U.N., FAO Plant Protect. Bull., 11, 25-30 (1963)

15. Bruehl, G. W., Keifer, H. H. Observations on the wheat streak mosaic in Washington, 1955-57. Plant Disease Reptr., 42, 32-5 (1958)

16. Bruehl, G. W., Toko, H., McKinney, H. H. Mosaics of Italian ryegrass and orchard grass in western Washington. Phytopathology, 47, 517 (1957)

17. Burnett, H. C. Species of Ficus susceptible to the fig mosaic virus. Proc. Florida State Hort. Soc., 1960, 73, 316-20 (1961)

18. Burnett, H. C. Additional hosts of the fig mosaic virus. Plant Disease Reptr., 46, 693 (1962)

19. Campbell, A. I. The inactivation of black currant reversion virus by heat therapy. Ann. Rept. Long Ashton Res. Sta., 1964, 89-92 (1965)

20. Cochran, L. C., Pine, T. S. Present status of information on host range and host reactions to peach mosaic virus. Plant Disease Reptr, 42, 1225-28 (1958)

21. Collingwood, C. A., Brock, A. M. Ecology of the black currant gall mite (Phytoptus ribis Nal.). J. Hort. Sci., 34, 176-82 (1959)

22. Condit, I. J., Horne, W. T. A mosaic of fig in California. Phytopathology, 23, 887-96 (1933)

23. Connin, R. V. Oversummering volunteer wheat in the epidemiology of wheat streak mosaic. J. Econ. Entomol., 49, 405-6 (1956)

24. Connin, R. V. The host range of the wheat curl mite, vector of wheat streak mosaic. J. Econ. Entomol., 49, 1-4 (1956)

25. Del Rosario, M. S., Sill, W. H., Jr. A method of rearing large colonies of an Eriophyid mite, Aceria tulipae (Keifer), in pure culture from single eggs or adults. $J$. Econ. Entomol., 51, 303-6 (1958)

26. Del Rosario, M. S., Sill, W. H., Jr. Additional biological and ecological characteristics of Aceria tulipae. J. Econ. Entomol., 57, 893-96 (1964) 
27. Del Rosario, M. S., Sill, W. H., Jr. Physiological strains of Aceria tulipae and their relationships to the transmission of wheat streak mosaic virus. Phytopathology, 55, 1168 75 (1965)

28. Dippenaar, B. J. Concentric ring blotch of citrus; its cause and control. S. African J. Agr. Sci., 1, 83-106 (1958)

29. Doreste, S. E. Advances gained in the control of the garlic mite, Aceria tulipae, a pest new to this crop in Venezuela. Ing. Agron., 11, 13-18 (1963)

30. Ebeling, W., Pence, R. A severe case of an uncommon type of in. jury by the fig mite. Bull. Calif. Dept. Agr., 89, 47-48 (1950)

31. Fellows, H. A survey of the wheat mosaic disease in western Kansas. Plant Disease Reptr., 33, 356-58 (1949)

32. Fellows, H., Schmidt, J. Reactions of Agrotricum hybrids to the virus of yellow streak mosaic of wheat. Plant Disease Reptr., 37, 349-51 (1953)

33. Finley, A. M. Wheat streak mosaic, a disease of sweet corn in Idaho. Plant Disease Reptr., 41, 589-91 (1957)

34. Flock, R. A., Wallace, J. M. Transmission of fig mosaic by the eriophyid mite Aceria ficus. Phytopathology, 45, 52-54 (1955)

35. Ford, R. E., Lambe, R. C. Wheat streak mosaic virus incidence in lowa. Plant Disease Reptr., 51, 389 (1967)

36. Fritzsche, R., Schmelzer, K., Schmidt, H. Evaluation of the ability of Tetranychus urticae Koch as a vector of plant viruses. Arch. Pflanzenschutz, 3, 89-100 (1967)

37. Gibson, W. W. Observations on the wheat curl mite, Aceria tulipae (K.) on wheat and sorghum sprouted under ripening wheat. $J$. Kansas Entomol. Soc., 30, 25-28 (1957)

38. Gibson, W. W., Painter, R. H. The -ccurrence of wheat curl mites, Aceria tulipae (K.), a vector of wheat streak mosaic on wheat seedlings grown from infested kernels. Trans. Kansas Acad. Sci. 59, 492-94 (1956)

39. Gibson, W. W., Painter, R. H. Transportation by aphids of the wheat curl mite, Aceria tulipae (K.) a vector of wheat streak mosaic virus. J. Kansas Entomol. Soc., 30, 147-53 (1957)

40. Gilmer, R. M., McEwen, F. L. Chlorotic fleck, an eriophyid mite injury of myrobalan plum. $J$. Econ. Entomol., 51, 335-37 (1958)

41. Ginai, M. A. Malformation of mango inflorescence. West Pakistan J. Agr. Res., 3, 248-51 (1965)

42. Gold, A. H., Houston, B. R., Oswald, J. W. Electron microscopy of elongated particles associated with wheat streak mosaic. Phytopathology, 43, 458-59 (1953)

43. Graniti, A. Fig mosaic in Italy and its possible vector. Riv. Frutticolt. Ortic., 16, 23-25 (1954)

44. Hall, C. C., Jr. A look at eriophyid life cycles. Ann. Entomol. Soc. Am., 60, 91-94 (1967)

45. Holmes, N. D., Swailes, G. E., Hobbs, G. A. The eriophyid mite, Aceria tulipae (K.) and silver top of grass. Can. Entomologist, 93, 64447 (1961)

46. Houston, B. R., Oswald, J. W. A mosaic disease of wheat, barley and oats new to California. Phytopathology, 42, 12 (1952)

47. How, S. C. Wheat streak mosaic virus on corn in Nebraska. Phytopathology, 53, 279-80 (1963)

48. Hutchins, L. M., Bodine, E. W. Cochran, I. C., Stout, G. L. Peach mosaic. In Virus diseases and other disorders with viruslike symptoms of stone fruits in North America. U. S. Dept. Agr., Handbook, 10, 26-36 (1951)

49. Jones, L. S., Wilson, N. S. Peach mosaic spreads throughout the growing season. Bull. Calif. Dept. Aor., 40, 117-18 (1951)

50. Jones, L. S., Wilson, N. S., Anthon, E. W. Transmission of cherry mottle leaf virus by an eriophyid mite. (In preparation)

51. Jones, L. S., Wilson, N. S., Burr, W., Barnes, M. M. Restriction of peach mosaic virus spread through control of vector mite. (In preparation)

52. Keifer, H. H. Eriophyid studies. Bull. Calif. Dept. Agr., 27, 181206 (1938)

53. Keifer, H. H. Eriophyid studies XII. Bull. Calif. Dept. Agr., 31, 11729 (1942)

54. Keifer, H. H. Erioplyyid studies XIV. Bull. Calif. Dept. Agr., 34, 18-38 (1945) 
55. Keifer, H. H. Eriophyid studies. B-8. Calif. Dept. Agr., Spec. Publ., 20 pp. (1962)

56. Keifer, H. H. Eriophyid studies. B-9. Calif. Dept. Agr., Spec. Publ., 20 pp. (1963)

57. Keifer, H. H. Eriophyid studies. B-11. Calif. Dept. Agr., Spec. Publ., 20 pp. (1964)

58. Keifer, H. H. Eriophyid studies. B-14, Calif. Dept. Agr., Spec. Publ., 20 pp. (1965)

59. Keifer, H. H. Eriophyid studies. B-21. Calif. Dept. Agr., Spec. Publ., 24 pp. (1966)

60. Keifer, H. H., Wilson, N. S. A new species of eriophyid mite responsible for the vection of peach mosaic virus. Bull. Calif. Dept. Agr., 44, 145-46 (1955)

61. King, C. L., Sill, W. H., Jr. 1959 wheat streak mosaic epiphytotic in Kansas. Plant Disease Reptr., 43, 1256-57 (1959)

62. Lange, W. H., Jr. Aceria tulipae (K.) damaging garlic in California. J. Econ. Entomol., 48, 612-13 (1955)

63. Lees, A. H. Reversion of black currants. Ann. Rept. Long Ashton Res. Sta., 1916, 31-34 (1917)

64. Lees, A. H. Statistical studies on the propagation of big bud and reversion disease of black currants. Ann. Rept. Long Ashton Res. Sta., 1922, 53-57 (1923)

65. Lees, A. H. Reversion disease of black currants: Means of infection. Ann. Rept. Long Ashton Res. Sta., 1924, 66 (1925)

66. Lloyd-Jones, C. P., Smith, B. D. The use of radioactive phosphorous to follow the movement of the black currant gall mite. Ann. Rept. Long Ashton Res. Sta., 1960, 133-34 (1961)

67. Massee, A. M. The black currant gall mite on red currants. Ann. Rept. E. Malling Res. Sta., Kent, 1926, 151-52 (1928)

68. Massee, A. M. The life history of the black currant gall mite, Eriophyes ribis (Westw.) Nal. Bull. Entomol. Res., 18, 297-309 (1928)

69. Massee, A. M. Transmission of reversion of black currants. Ann. Rept. E. Malling Res. Sta., Kent, 1951, 162-65 (1952)

70. McKinney, H. H. Mosaic diseases of wheat and related cereals. U.S. Dept. Agr. Circ. 442, 23 pp. (1937)
71. McKinney, H. H. Tests of varieties of wheat, barley, oats and corn for reaction to wheat streak mosaic virus. Plant Disease Reptr., 33, 359-69 (1949)

72. McKinney, H. H., Brakke, M. K., Ball, E. M., Staples, R. Wheat streak mosaic virus in the Ohio Valley. Plant Disease Reptr., 50, 951-53 (1966)

73. McKinney, H. H., and Fellows, H. Wild and forage grasses found to be susceptible to the wheat streak mosaic virus. Plant Disease Reptr., 35, 441-42 (1951)

74. McKinney, H, H., Sando, W, J, Susceptibility and resistance to the wheat streak mosaic virus in the genera, Triticum, Agropyron, Secale, and certain hybrids. Plant Disease Reptr., 35, 476-79 (1951)

75. McLarty, H. R. Currant. In 22nd Ann. Rept. Can. Plant Disease Surv., 82 (1942)

76. McLarty, H, R., Lott, T. B., Milbrath, J. A., Reeves, E. L., Zeller, S. M. Mottle leaf. In Virus diseases and other disorders with viruslike symptoms of stone fruits in North America. U.S. Dept. Agr., Agr. Handbook 10, 106-11 (1951)

77. McNeal, F. H., Dubbs, A. L. Infuence of wheat streak mosaic on winter wheat in an area of Montana in 1955. Plant Disease Reptr., 40, 517-19 (1956)

78. Meiners, J. P. Wheat streak mosaic found in Washington. Plant Disease Reptr., 38, 714-15 (1954)

79. Mulligan, T. E. Transmission of ryegrass mosaic virus. Ann. Rept. Rothamstead Expt. Sta., 1957, 110-11 (1958)

80. Mulligan, T. E. The transmission by mites, host range and properties of ryegrass mosaic virus. $A n n$. Appl. Biol., 48, 575-79 (1960)

81. Mumford, E. P. On the fauna of the diseased big bud of the black currant Ribes nigrum $L$. with a note on some fungus parasites of the gall mite Eriophyes ribis (Westw.) Nal. Marcellia, 27, 29-62 (1931)

82. Narayanasamy, P., Ramakrishnan, $K$. Studies on the sterility mosaic disease of pigeon pea. 1. Transmission of the disease. Proc. Indian Acad. Sci., Sect. B, 62, 73-86 (1965)

83. Nariani, T. K., Seth, M. C. Role of eriophyid mites in causing malfor- 
mation disease of mango. Indian Phytopathol., 15, 231-34 (1963)

84. Nault, L. R., Briones, M. L., Williams, L. E., Barry, B. D. Relations of the wheat curl mite to kernel red streak of corn. Phytopathology, 57, 986-89 (1967)

85. Niemeyer, L., Bode, $O$. Uber den Virusnachweis bei Reben (Bemerkungen $z u$ einer Veröffentlichung von G. Ochs) Z. Pflanzenkrankh. Pflanzenschutz, 66, 640-44 (1959)

86. Ochs, G. ttber drei Viren als Erreger von Rebkrankheiten. 2. Pflanzenkrankh., P flansenschuts, 65, 11-17 (1958)

87. Ochs, G. Untersuchungen über die Verbreitung der Rebenviren durch Vektoren. Naturwissenschaften, 45, 193 (1958)

88. Ochs, G. Ubertragungsversuche von drei Rebviren durch Milben und Insekten 2. Angew. Zool., 47, 485-91 (1960)

89. Oldfield, G. N. The biology and morphology of Eriophyes emarginatae, a Prunus finger gall mite, and notes on $E$. prunidemissae. Ann. Entomol. Soc. Am., 62, 269-77 (1969)

90. Oldfield, G. N., Wilson, N. S. A method of establishing colonies of Eriophyes insidiosus, the vector of the peach mosaic virus. (In preparation)

91. Oliinyk, A. M. Transmission of wheat streak mosaic virus by mites: Aceria tulipae. Mikrobiol. 2h., Acad. Nauk Ukr RSR, 29, 338-41 (1967)

92. Orlob, G. B. Feeding and transmission characteristics of Aceria tulipae Keifer as vector of wheat streak mosaic virus. Phytopathol. Z., 55, 218-38 (1966)

93. Orlob, G. B. Epidemiology of wheat streak mosaic in South Dakota 1962-66. Host range studies. Plant Disease Reptr., 50, 819-21 (1966)

94. Orlob, G. B. Relationships between Tetranychus urticae Koch and some plant viruses. Virology, 35, 121-33 (1968)

95. Paliwal, Y, C., Slykhuis, J. T. Loca1ization of wheat streak mosaic virus in the alimentary canal of its vector, Aceria tulipae K. Virology, 32, 344-53 (1967)

96. Pine, T. S. Host range and strains of peach mosaic virus. Phytopathology, 55, 1151-53 (1965)

97. Pine, T. S., Cochran, L. C. Peach mosaic virus in horticultural plum varieties. Plant Disease Reptr., 46, 495-97 (1962)

98. Pop, I. V. The streak mosaic of wheat in the Rumanian People's Republic. Phytopathol. Z., 43, 325-36 (1962)

99. Prasad, A., Singh, H., Shukla, T. N. Present status of mango malformation disease. Indian J. Hort., 22, 254-64 (1965)

100. Pratt, R. M. (Personal communication, 1967)

101. Proeseler, G., Kegler, H. Transmission of a latent virus from plum by gall mites (Eriophyidae). Deut. Akad. Wiss. Berlin, Monatsber., 8, 472-76 (1966)

102. Puttarudriah, M., Channabasavanna, G. P. An eriophyid mite as a new pest of garlic in Mysore. Food Agr. Organ, U.N., FAO Plant Protect Bull., 6, 123-24 (1958)

103. Rai, B., Singh, N. An observation on recovery from malformation in mango sapling. Current Sci. (India) 36, 525-26 (1967)

104. Razvyazkina, G. M., Kopkova, E. A., Belyanchikova, Y. V. Wheat streak mosaic. Zashchita Rastot Vreditelei Boleznei, 8, 54-55 (1963)

105. Rosi-DeSimons, N. E. Four new mites reported in Argentina. Idia (Buenos Aires), 204 (1964)

106. Rossouw, D. J., Smith, A. J. The relation of Calacarus citrifolii Keifer to concentric ring blotch of citrus. S. African Citrus J., 354, 7-9 (1963)

107. Schulz, J. T. Tetranychus telarius (L.) new vector of Virus $Y$. Plant Disease Reptr., 47, 594-96 (1963)

108. Seth, M. L. Transmission of pigeon pea (Cajonus cajan) sterility (virus) by an eriophyid mite. Indian Phtytopathol., 15, 225-27 (1963)

109. Seth, M. I., Nariani, T. K. A note on methyl bromide fumigation of mango seedlings affected with the malformation disease. Indian Phytopathol., 19, 390 (1966)

110. Shepard, J. F., Carroll, T. W. Electron microscopy of wheat streak mosaic virus particles in infected plant cells. $\delta$. Ultrastruct. Res., 21, 145-52 (1967)

111. Shtein-Margolina, V. A., Cherni, N. E., Razvyazkina, G. M. Wheat streak mosaic virus in cells of the plant and mite vector. Dokl. Akad. 
Nauk. SSSR., 169, 1446-48 (1966)

112. Sill, W. H., Jr., Agusiobo, P. C. Host range studies of the wheat streak mosaic virus. Plant Disease Reptr., 39, 633-42'(1955)

113. Sill, W. H., Jr., Connin, R. V. Summary of the known host range of the wheat streak mosaic virus. Trans. Kansas Acad. Sci., 56, 41117 (1953)

114. Sill, W. H., Jr., Del Rosario, M. S. Transmission of wheat streak mosaic virus to corn by the eriophyid mite Aceria tulipae. Phytopathology, 49, 396 (1959)

115. Sill, W. H., Jr., Fellows, H. Symptom expression of the wheat streak mosaic virus disease as affected by temperature. Plant Disease Reptr., 37, 30-33 (1953)

116. Sill, W. H., Jr., Fellows, H., King, C. L. Kansas wheat mosaic situation (1953 4). Plant Disease Reptr., 39, 29-30 (1955)

117. Slykhuis, J. T. Virus diseases of cereal crops in South Dakota. $S$. Dakota State Coll. Agr. Expt. Sta. Tech. Bull. 11, 29 pp. (1952)

118. Slykhuis, J. T. The relation of Aceria tulipae (K.) to streak mosaic and other chlorotic symptoms of wheat. Phytopathology, 43, 48485 (1953)

119. Slykhuis, J. T. Aceria tulipae Keifer in relation to the spread of wheat streak mosaic. Phytopathology, 45, 116-28 (1955)

120. Slykhuis, J. T. Wheat spot mosaic caused by a mite-transmitted virus associated with wheat streak mosaic. Phytopathology, 46, 682-87 (1956)

121. Slykhuis, J. T. A survey of virus diseases of grasses in northern Europe. Food Agr. Organ., U.N., F AO Plant Protect. Bull., 6, 12934 (1958)

122. Slykhuis, J. T. Current status of mite-transmitted plant viruses. Proc. Entomol. Soc. Ontario, 90, 22-30 (1960)

123. Slykhuis, J. T. Eriophyid mites in selation to the spread of grass viruses in Ontario. Can. J. Plant Sci., 41, 304-8 (1961)

124. Slykhuis, J. T. Mite transmission of plant viruses. In Biological transmission of disease agents, 41-61. (Maramorosch, K., Ed., Academic
Press, New York, 192 pp., 1962)

125. Slykhuis, J. T. An international survey for virus diseases of grasses. Food Agr. Organ., U.N., FAO Plant Protect. Bull., 10, 1-16 (1962)

126. Slykhuis, J. T. Mite transmission of plant viruses. In Advances in Acarology, 1, 326-40. (Naegele, J. A., Ed., Comstock Press, Ithaca, N.Y., 479 pp., 1963)

127. Slykhuis, J. T. Current research on mites in relation to plant virus transmission. Phytoprotection, 45, 101-7 (1964)

128. Slykhuis, J. T. Mite transmission of plant viruses. In Advances in Virus Research, 11, 97-137. (Smith, K. M., Lauffer, M. A., Eds., Academic Press, New York and London, 425 pp., 1965)

129. Slykhuis, J. T. Methods for experimenting with mite transmission of plant viruses. In Methods in Virology, I., Chap. 10, 347-68. (Maramorosch, K., Kobrowski, H., Eds., Academic Press, New York, 640. pp., 1967)

130. Slykhuis, J. T., Andrews, J. E., Pittman, U. J. Relation of date of seeding winter wheat in southern Alberta to losses from wheat streak mosaic, root rot and rust. Can. J. Plant Sci., 37, 113-27 (1957)

131. Smalley, E. B. The production on garlic by an eriophyid mite of symptoms like those produced by viruses. Phytopathology, 46, 34647 (1956)

132. Smith, B. D. The behavior of the black currant gall mite (Phytoptus i.e. Cecidophyes ribis Nal.) during the free living phase of its life cycle. Ann. Rept. Long Ashton Res. Sta., 1959, 130-36 (1960)

133. Smith, B. D. Effect of temperature and photoperiod on black currants and on the behavior of the gall mite (Phytoptus i.e. Cecidophyes ribis Nal.). Ann. Rept. Long Ashton Res. Sta., 1959, 137-38 (1960)

134. Smith, B. D. Population studies of the black currant gall mite ( $P$ hytoptus ribis Nal.). Ann. Rept. Long Ashton Res. Sta., 1960 , 120-24 (1961)

135. Smith, B. D. Experiments in the transfer of the black currant gall 
mite (Phytoptus ribis Nal.) and of reversion. Ann. Rept. Long Ashton Res. Sta., 1961, 170-72 (1962)

136. Smith, B. D. A field study of the spread of the black currant gall mite (Phytoptus ribis Nal.) and of the virus disease reversion. Ann. Repi. Long Ashton Res. Sta., 1962, 124-29 (1963)

137. Smith, B. D., Corke, A. T. K. Effect of (2-chloroethyl) trimethylammonium chloride on the eriophyid gall mite Cecidophyopsis ribis $\mathrm{Nal}$., and three fungus diseases of black currant. Nature, 212, 64344 (1966)

138. Smith, K. M. A textbook of plant virus diseases. (Little, Brown \& Co., Boston, 652 pp., 1957)

139. Somsen, H. W. Development of migratory form of wheat curl mite. J. Econ. Entomol., 59, 1283-84 (1966)

140. Staples, R., Allington, W. B. Streak mosaic of wheat in Nebraska and its control. Nebraska Agr. Expt. Sta. Bull., 178, 1-41 (1956)

141. Staples, R., Brakke, M. Relation of Agropyron repens mosaic and wheat streak mosaic viruses. Phytopathology, 53, 969-72 (1963)

142. Sutic, D., Tosic, M. The virus of wheat streak mosaic in Yugoslavia. Zastita Bilja, 79, 307-14 (1964)

143. Swarbrick, T. Berry, W. E. Further observations on the incidence and spread of reversion and big bud on black currants. Ann. Rept. Long Ashton Res. Sta., 1936, 12432 (1937)

144. Taksda, G. The ecology of cold hardiness in different populations of the black currant gall mite, Cecidophyopis ribis. Entomol. Exptl. Appl., 10, 377-86 (1967)

145. Thresh, J. M. A vein pattern of black currant leaves associated with reversion disease. Ann. Rept. E. Malling Res. Sta., Kent, 1962, 97-98 (1963)

146. Thresh, J. M. Abnormal black currant foliage caused by the gall mite, Phytoptus ribis Nal. Ann. Rept. E. Malling Res. Sta., Kent, 1962, 99-100 (1963)

177. Thresh, J. M. Increased susceptibility of the mite vector (Phytoptus ribis Nal.) caused by infection with black currant reversion virus. Nature, 202, 1028 (1964)

148. Thresh, J. M. Association between black currant reversion and its gall mite vector (Phytoptus ribis Nal.). Nature, 202, 1085-87 (1964)

149. Thresh, J. M. Warm water treatments to eliminate the gall mite Phytoptus ribis Nal. from black currant cuttings. Ann. Rept. E. Malling Res. Sta., Kent, 1963, 131-32 (1964)

150. Thresh, J. M. Field experiments on the spread of black currant reversion virus and its gall mite vector (Phytoptus ribis Nal.). Ann. Appl. Biol., 58, 219-30 (1966)

151. Thresh, J. M. Increased susceptibility of black currant bushes to Phytoptus ribis following infection with virus. Ann. Appl. Biol., 60, 455-67 (1967)

152. Tiits, A. Some observations on black currant reversion when the virus is transmitted by grafting. Izvest. Akad. Nauk, Eston. SSR., Ser. Biol., 4, 267-71 (1964)

153. Timian, R. G., Bissonette, H. L. Wheat streak mosaic virus in North Dakota. Plant Disease Reptr., 48, 703 (1964)

154. Tuttle, D. M., Baker, E. W. Spider mites of Southwestern United States and a revision of the family Tetranychidae. (U. Arizona Press, Tucson, 143 pp., 1968)

155. Van der Merwe, G. G., Coates, T. J. Biological study of the grey mite Calacarus citrifolii Keifer. $S$. African J. Agr. Sci., 817-24 (1965)

156. Van Eyndhoven, G. L. The red currant gall mite, Cecidophyopsis selachodon n. sp. Entomol. Ber., 27, 149-51 (1967)

157. Vashisth, K. S., Nagaich, B. B. Morus indica, an additional host of fig mosaic. Indian Phytopathol., 18, 315 (1965)

158. Vukovits, G. Beobachtungen and $\mathrm{Un}$ tersuchungen über die an Prunus Arten vorkommende Sternflecken(Kräusel) Krankheit. Pflanzenschutz Ber., 26, 1-17 (1961)

159. Wadsworth, D. F., Barley and wheat mosaic in Oklahoma. Plant Disease Reptr., 33, 482-83 (1949)

160. Wallin, J. R. Field observations of 
wheat mosaic in Kansas, Nebraska and Iowa. Plant Disease Reptr. 34, 211-12 (1950)

161. Walters, H. J. Virus diseases of small grains in Wyoming. Plant Disease Reptr., 38, 836-37 (1954)

162. Warburton, C., Embleton, A. L. The life history of the black currant gall mite Eriophyes (Phytoptus) ribis Westw. Linnean Soc. $J$. Zool., 28, 366-78 (1901-03)

163. Williams, L. E., Gordon, D. T. Nault, L. R., Alexander, L. J., Bradfute, O. E., Findley, W. R. A virus of corn and small grains in Obio and its relation to wheat streak mosaic virus. Plant Disease Reptr., 51, 207-11 (1967)

164. Wilson, N. S., Cochran, L. C. Yellow spot, an eriophyid mite injury on peach. Phytopathology, 42, 443-47 (1952)
165. Wilson, N. S., Jones, L. S. Unpublished data Fruit Disease Vector Investigations, Fruit Insects Research Branch, U. S. Dept. Agr., A.R.S., Entomol. Res. Div. (195565)

166. Wilson, N. S., Jones, L. S., Cochran, L. C. An eriophyid mite vector of the peach mosaic virus. Plant. Disease Reptr., 39, 889-92 (1955)

167. Wilson, N. S., Oldfield, G. N. New species of eriophyid mites from western North America with a discussion of eriophyid mites on Populus. Ann. Entomol. Soc. Am., 59, 585-99 (1966)

168. Wilson, N. S., Oldfield, G. N. Unpublished data Fruit Disease Vector Investigations, Fruit Insects Research Branch, $U$. S. Dept. Agr., A.R.S., Entomol. Res. Div. (1969) 